\title{
THE REVEALED DEMAND FOR HARD VS. SOFT NEWS: EVIDENCE FROM ITALIAN TV VIEWERSHIP
}

\author{
Marco Gambaro \\ Valentino Larcinese \\ Riccardo Puglisi \\ James M. Snyder Jr. \\ Working Paper 29020 \\ http://www.nber.org/papers/w29020
NATIONAL BUREAU OF ECONOMIC RESEARCH
1050 Massachusetts Avenue
Cambridge, MA 02138
July 2021

Corresponding author: Riccardo Puglisi, riccardo.puglisi@unipv.it; this paper contains statistical analyses done at Harvard University and the University of Pavia on data provided by AUDITEL ${ }^{\mathrm{TM}}$ We thank Andrea Prat, David Stromberg, and seminar participants at Ancona, the Alghero Media Workshop 2018, Bologna, Bolzano, Johns Hopkins, the NYU/LSE Conference, Keio University, the 2nd Economics of Media Bias Workshop in Lausanne, the SISP 2016 Conference in Milan, Nottingham, Venice Ca' Foscari, Genova and Zurich. The views expressed herein are those of the author and do not necessarily reflect the views of the National Bureau of Economic Research.

NBER working papers are circulated for discussion and comment purposes. They have not been peer-reviewed or been subject to the review by the NBER Board of Directors that accompanies official NBER publications.

(C) 2021 by Marco Gambaro, Valentino Larcinese, Riccardo Puglisi, and James M. Snyder Jr.. All rights reserved. Short sections of text, not to exceed two paragraphs, may be quoted without explicit permission provided that full credit, including () notice, is given to the source. 
The Revealed Demand for Hard vs. Soft News: Evidence from Italian TV Viewership Marco Gambaro, Valentino Larcinese, Riccardo Puglisi, and James M. Snyder Jr.

NBER Working Paper No. 29020

July 2021

JEL No. D72

\begin{abstract}
We analyze minute-by-minute, individual level data on viewership for Italian TV news broadcasts (from AUDITEL ${ }^{\mathrm{TM}}$ ), matched with detailed data on content (from Osservatorio di Pavia). We are interested in the behavior of viewers, and in particular in their decision to switch away from a news program as a function of the type of story they are currently watching. Somewhat surprisingly, we find that "soft" news systematically induces viewers to switch away, even more than "hard" news. On the other hand, sensational stories about crime, accidents and disasters are associated with less switching. We also find significant differences in this switching behavior according to gender, age, and the specific TV channel being watched. For example, young people are relatively more likely to switch away from hard news than soft news, compared to older people.
\end{abstract}

Marco Gambaro

Department of Economics

Management and Quantitative Methods

Università degli Studi di Milano

Via Conservatorio, 720122 MILANO (MI)

Italy

marco.gambaro@unimi.it

Valentino Larcinese

Department of Government and STICERD

London School of Economics

Houghton Street, London WC2A 2AE, UK

V.Larcinese@1se.ac.uk

\author{
Riccardo Puglisi \\ Department of Political and \\ Social Sciences \\ University of Pavia \\ Corso Strada Nuova 65 \\ 27100 Pavia \\ Italy \\ riccardo.puglisi@unipv.it \\ James M. Snyder Jr. \\ Harvard University \\ 1737 Cambridge Street, CGIS \\ Knafel Building Room 413 \\ Cambridge, MA 02138 \\ and NBER \\ jsnyder@gov.harvard.edu
}




\begin{abstract}
We analyze minute-by-minute, individual level data on viewership for Italian TV news broadcasts (from AUDITEL ${ }^{\mathrm{TM}}$ ), matched with detailed data on content (from Osservatorio di Pavia). We are interested in the behavior of viewers, and in particular in their decision to switch away from a news program as a function of the type of story they are currently watching. Somewhat surprisingly, we find that "soft" news systematically induces viewers to switch away, even more than "hard" news. On the other hand, sensational stories about crime, accidents and disasters are associated with less switching. We also find significant differences in this switching behavior according to gender, age, and the specific TV channel being watched. For example, young people are relatively more likely to switch away from hard news than soft news, compared to older people.
\end{abstract}

"If you don't eat yer meat, you can't have any pudding. How can you have any pudding if you don't eat yer meat?"-

The Teacher, Another Brick in the Wall (Part 2), Pink Floyd

\title{
1 Introduction
}

Political scientists and communication scholars have documented a trend in news production and consumption away from "hard" news - e.g., stories about public policies, the economy, the general functioning of government, and foreign affairs - towards "soft" news about sports, fashion, food, travel, celebrity gossip, and the like (Zaller 1999, Patterson 2000). ${ }^{1}$ This has led scholars to different conclusions about the consequences of soft news for democratic politics. Some worry the proliferation of soft news harms civil discourse, public opinion and voter knowledge (Zaller 1999, Patterson 2000, Prior 2003). Others suggest that soft news is beneficial — for example, by capturing the interest of citizens who otherwise would be inattentive to news, and thus helping political knowledge "trickle down" to a larger set of citizens (Baum 2002 and 2010, Baum and Jamison 2006, Prat and Strömberg 2005).

\footnotetext{
${ }^{1}$ See Reinemann et al. [2012] for a discussion of how communication scholars have operationalized the distinction between hard and soft news.
} 
Empirical studies seeking to document patterns of viewership, or seeking to estimate the impact of soft news consumption on political knowledge and behavior, are typically based either on aggregate measures or on survey data. Due to the presence of strong social norms towards "civic-mindedness," self-reported behavior might not be an accurate indicator of actual news viewership. Social-desirability bias might lead respondents to systematically overstate their consumption of hard news and understate how much they watch soft news. Moreover the amount of over and underreporting could be correlated with both observed and unobserved characteristics of respondents. $^{2}$

In this paper we study the actual behavior of individual news consumers, rather than selfreports. More precisely, we use the minute-by-minute individual level ratings data for all major Italian television news broadcasts during the two-year period, January 1, 2009 through December 31, 2010. These ratings are provided by the AUDITEL ${ }^{\mathrm{TM}}$ consortium, which uses meter-based data from Nielsen. In addition to the obvious advantages stemming from the use of "revealed preferences," data at the individual level allow us to investigate the details of TV viewership, with no need to infer individual behavior from aggregate data.

We match the TV ratings data with equally highly granular data on the issues covered by Italian national evening news broadcasts, minute by minute. This data is provided by the Osservatorio di Pavia. ${ }^{3}$ Merging the two databases tells us which news story each individual in the sample is watching - or not watching - for each minute of the major evening news programs.

First, we use this data to describe the overall patterns of news viewership in the Italian TV audience. Our descriptive analysis reveals heterogeneity in viewing habits and a relatively clear typology. A substantial share of Italian adults never or rarely watch TV news. A second type watches the news regularly, and these people often watch the entire program. A third type watches news more irregularly and often watches only part of the broadcast. Second, the best predictor of TV news watching is total TV watching. This means that demographic variables

\footnotetext{
${ }^{2}$ For example Prior (2009) estimates that US respondents in the National Annenberg Election Study overreported their total news consumption threefold, on average. He also finds that the degree of over-reporting varies significantly across demographic groups.

${ }^{3}$ The Osservatorio di Pavia (www.osservatorio.it/en) is an independent institute of research that is specialized on media analysis, with a specific focus on monitoring media freedom and pluralism.
} 
that predict overall TV consumption, such as age, gender and education, also tend to predict TV news consumption. As a consequence older and less educated people, and women, watch more TV news than average.

We then conduct regression analyses to study the minute-by-minute switching behavior of all TV news viewers. In these regressions the dependent variable indicates whether or not a given viewer changed channels (or turned off the television) during each minute in which he or she was watching the news. The key independent variables indicate the type of news story that was being aired during or just prior to the switch, distinguishing between hard news, soft news and sensational news stories.

Our focus is on the difference in the propensity to switch away during a hard news story than during a soft news story. When we do not include channel-specific fixed effects, i.e., when looking at the overall variation in switching behavior between and within TV news stories, we find that the propensity to switch away during a soft news story is systematically higher than during a hard news story, but for the first 5-minute block. Moreover, this difference in the propensity to switch away increases steadily as the news program proceeds. We find an even stronger difference in the propensity to switch away during a soft news story than during a sensational story.

When including channel-specific fixed effects, i.e., when exploiting only within-program variation, the differences in switching behavior when watching hard versus soft news are smaller than those estimated without channel fixed effects, but they are still significant and sizable in the last 10-15 minutes of each show. We also find significant differences in the propensity to switch away during hard versus soft news according to the gender, the age and the specific TV news show the viewer watches.

Overall, these findings are inconsistent with the simple hypothesis that TV consumers always seek entertainment rather than politically relevant information.

The paper is organized as follows: in the next section we provide some background information on the Italian television system and introduce the ratings data and the TV content data. We also provide basic descriptive statistics and discuss some of the advantages of using data 
based on actual behavior rather than self-reported information from surveys. In section 3 we present our descriptive analysis of viewership by type of news, while in section 4 we discuss our regression results on individual switching behavior. Section 5 concludes by summarizing our findings and proposing possible next steps.

\section{Background and Data}

\subsection{A Brief Introduction to Italian TV News}

In Italy there are seven national channels. Three channels are part of the national broadcasting corporation (RAI), which is state-owned. A tacit agreement between the main political forces is that RAI 1 is typically controlled by the government, RAI 2 by the right and RAI 3 by the left. Three channels - Rete 4, Canale 5 and Italia 1-are part of the Mediaset network and are controlled by Silvio Berlusconi, who was the leader of the right-wing coalition for two decades and three times prime minister. ${ }^{4}$ During the period studied in this paper, 2009-2010, Silvio Berlusconi was Italy's prime minister and therefore, in addition to the Mediaset Channels, he also had substantial influence over the RAI 1 and RAI 2 channels. Prime time (20.30-22.30) audience shares for RAI and Mediaset in 2010 were $44 \%$ and 37\%, respectively. The main RAI channel (RAI 1) had a share of about 22.5\%, while the main Mediaset channel (Canale 5) had 18.5\%. Shares for other times of the day are only slightly different. The last national channel, La 7, had a small audience share, only about $3 \%$, and is not part of our sample. ${ }^{5}$ In addition to these channels, which are available everywhere, there are many local channels and, after the introduction of the digital signal from 2008 to 2013, many "specialized" digital channels. These other channels, however, accounted for a small share of the audience in 2009-2010.

Each of the seven national channels broadcasts several TV news shows during the day. As in other countries, the most highly watched news shows are in the evening, between $6.30 \mathrm{pm}$ and

\footnotetext{
${ }^{4}$ In 2009-2010 Silvio Berlusconi owned by far the largest share of the company, and owned more than 50\% until 2005. No other single shareholders owned more than 4\%. Berlusconi's son Pier Silvio was vice-president of Mediaset, and his daughter Marina sat on the administration board.

${ }^{5}$ From 2001 to 2013, La 7 was owned by Telecom Italia, the former state-owned telecom monopoly. It was sold to its current owner Cairo Editore in March 2013. La 7's audience share increased considerably in the last months of 2010.
} 
$9.00 \mathrm{pm} .{ }^{6}$ The political leaning of each RAI news show tends to reflect the general orientation of its respective channel. During 2009-2010, the evening news broadcast of the main state-owned channel RAI 1, TG1, was controlled by the ruling right-wing coalition led by Silvio Berlusconi. The news broadcast of RAI 2, TG2, was also controlled by the ruling right-wing coalition, while RAI3's news program, TG3, was controlled by the left-wing coalition. ${ }^{7}$

There is also some interesting variation inside the group of Berlusconi-owned news broadcasts. Mediaset 5 is by far the most viewed Mediaset channel. The main news broadcast aired on Mediaset 5, TG5, was (and still is) more politically moderate in coverage than the TG4 broadcast of Rete 4. It was also more moderate than Studio Aperto, the main news program aired on Italia 1, which appeals to a younger audience.

In what follows we will refer to the RAI channels as, respectively, RAI 1, RAI 2 and RAI 3. We will refer to the Mediaset channels Rete 4, Canale 5 and Italia 1 as Mediaset 4, Mediaset 5 and Mediaset 6, respectively. As shown in Table 2 below, the most popular TV news shows are RAI 1 and Mediaset 5. Despite its relatively early time-slot, the third most popular show is RAI3. Because of its political leaning and focus, the conventional wisdom is that it has an especially loyal audience.

\subsection{The AUDITEL Data}

We use individual level, minute-by-minute ratings data for Italian TV, provided by AUDITEL. We focus on the 24 months from January 2009 to December 2010 and restrict our analysis to evening TV news broadcasts.

During this period, AUDITEL collected data from a panel of about 10,000 Set Top Box de-

\footnotetext{
${ }^{6}$ In 2010 the evening national news programs began at $6.30 \mathrm{pm}$ on Italia 1 (lasting about 25-30 minutes, on average), at $7.00 \mathrm{pm}$ on both RAI 3 and Rete 4 (lasting about 30 minutes on both), at 8.00pm on both RAI 1 and Canale 5 (lasting about 30-35 minutes on both channels), at $8.30 \mathrm{pm}$ on RAI 2 (where it lasted until about $9.00 \mathrm{pm})$. These times are the same today, with only a slight change for Channel 4 .

${ }^{7}$ The board of directors of RAI is composed of 9 members. Seven members are chosen by a Parliamentary committee and therefore reflect the composition of parliament - typically four members are appointed by the majority and three by opposition parties. The remaining two members, including the director, are nominated by the Minister of the Economy. The board of directors is therefore clearly composed of personnel which is close to the main political parties and skewed in favor of the parties in government. Formally, the board of directors then appoints the directors of the channels and of the news shows. Not surprisingly such appointments are subject to intense political pressure. Leaving one channel to the opposition is an informal convention.
} 
vices connected to the televisions of about 5,000 families that includes about 15,000 individuals. Each Set Top Box records second by second if a television is switched on and to what channel it is tuned, collecting information automatically, continuously, and passively. Each participating family has a special remote control with buttons for each family member to press when they are watching TV. The data are collected each night and are processed by 10 AM, when the audience data are released to televisions and advertisers. The controls included technical verification of each Set Top Box and analysis of abnormal behavior of TV sets and family members. The participating families receive no monetary compensation, but they receive an in-kind gift. The turnover in the panel is about 8-10\% per year. New participants are selected from a sample of 100,000 individuals who are interviewed each year to assess the technological equipment and devices of Italian families, the technologies employed to receive television signals, and the use of services such as pay TV. The sample is stratified by age, gender, education, and regions.

One important advantage of the AUDITEL data is that it tracks actual behavior. Much previous work relies on self-reported data from surveys, which can be highly inaccurate. For example Prior [2009] shows that U.S. citizens display a strong, systematic tendency to overstate the frequency with which they watch TV news broadcasts. He does this by comparing the self-reported frequency of viewership with partially aggregated viewership data from Nielsen ratings. ${ }^{8}$ It is likely that the propensity to overstate news consumption is due at least in part to social-desirability bias.

It appears that Italians also substantially overstate how much TV news they watch when they are surveyed. Consider, for example, the widely used Italian National Election Study (ITANES). ${ }^{9}$ ITANES asks respondents how many days per week they watch television news, from zero to seven. We compare these responses with the AUDITEL data in Figure $1 .^{10}$

\footnotetext{
${ }^{8}$ Comparing National Annenberg Election Survey data for 2009 and Nielsen ratings, Prior shows that on average U.S. citizens overstate TV news viewership by a factor of three. This multiple is as high as eight for specific subgroups, such as young people aged from 18 to 34 .

${ }^{9}$ ITANES is the Italian National Election Study, see http://www.itanes.org/en/questionnaires/

${ }^{10}$ Since the AUDITEL data cover 2009 and 2010, we use the closest available ITANES study, which was conducted in 2008.
} 


\section{Figure 1: Frequency of TV News Watching AUDITEL Ratings vs. ITANES Self-Reports}

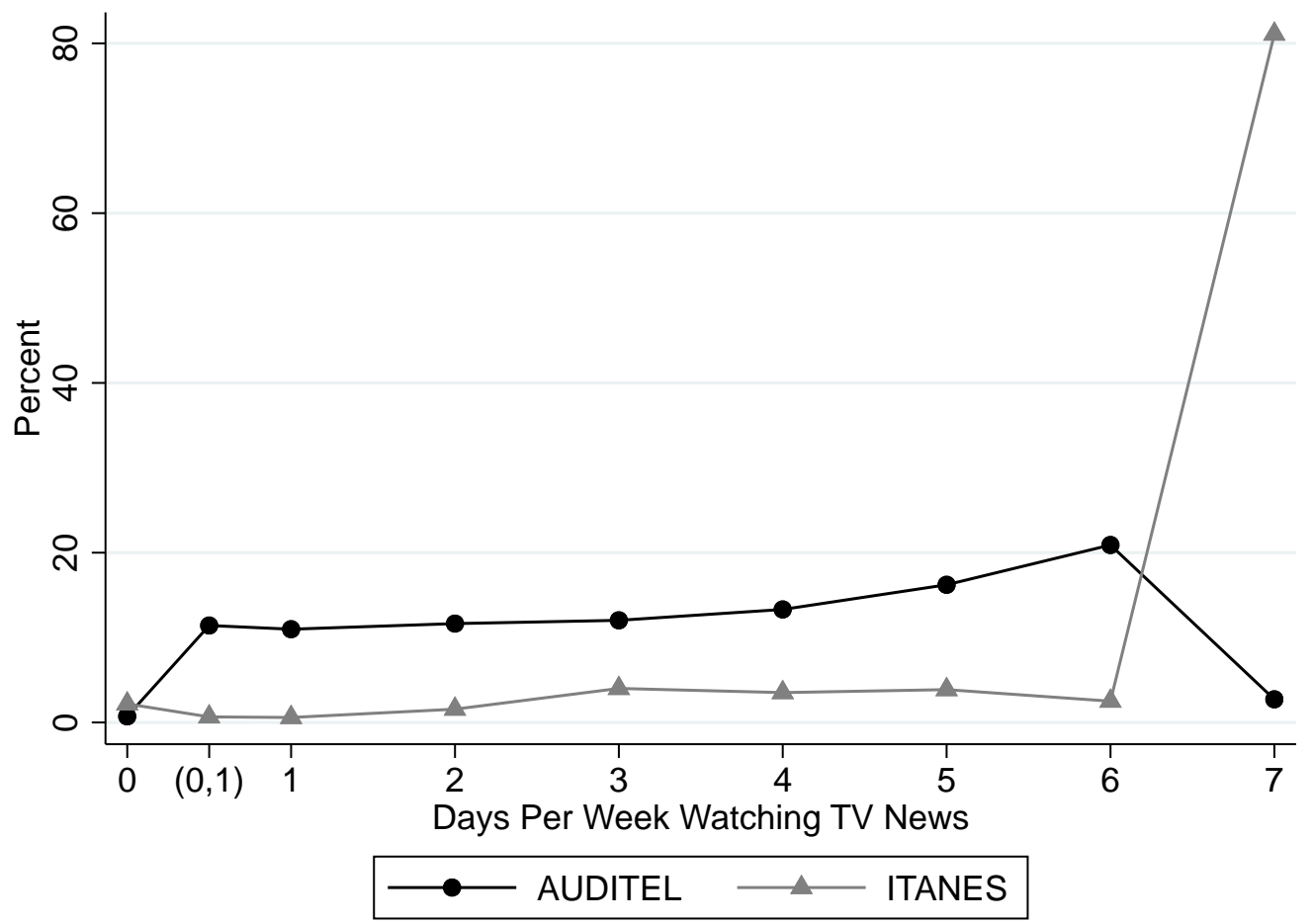

Clearly, there are large differences between actual viewership from AUDITEL and selfreports from ITANES. While 80 percent of ITANES respondents say they watch the news every day, according to the AUDITEL data only slightly more than $20 \%$ of viewers watch TV news six or seven days per week. And the percentage actually watching news every day is less than $3 \% .^{11,12}$

\footnotetext{
${ }^{11}$ The AUDITEL numbers are calculated as follows. For each individual $i$ and each day $t$ we compute the total number of minutes the individual watched any TV news show (this includes daytime and late-night news programs as well as the evening news). If individual $i$ watched at least five minutes of TV news on day $t$, then we count that individual as having "watched the news" on day $t$, and we set $w_{i t}=1$. Otherwise, we set $w_{i t}=0$. We think that a five-minute minimum is a generous lower bound for defining what people mean when they say they "watch" a program. We then average $w_{i t}$ over all days that individual $i$ is in the AUDITEL sample and multiply by seven to obtain the average number of days of TV news watching per week.

${ }^{12}$ When answering the question about TV news viewership, ITANES respondents might have in mind all days during the year, or they might focus on those days when they actually watched some TV. For example, they might not watch TV while on holiday, and might also disregard those days when answering the question. So, as a robustness check, we computed the AUDITEL analogue by limiting attention to those days when each individual watched at least some TV. Computed this way, about $36 \%$ of individuals watch at least 5 minutes
} 


\section{Figure 2: TV News Watching, Favorite Channel AUDITEL Ratings vs. ITANES Self-Reports}

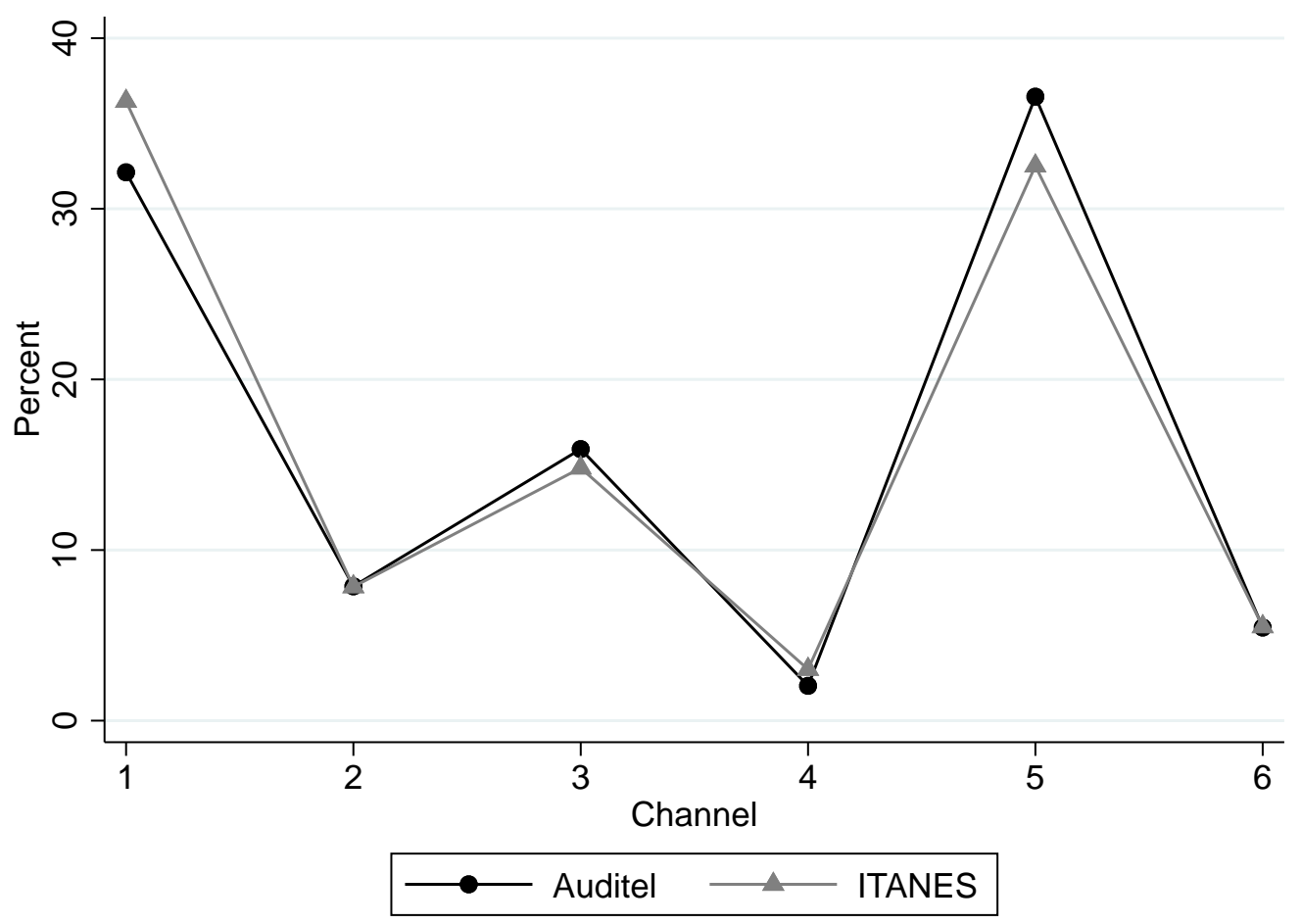

It is also interesting to check the differences between self-reported data and ratings data along other dimensions. For example, ITANES asks each respondent what is their favourite TV news program. Assuming each respondent watches only that program, we can construct a survey-based estimate of the distribution of viewership shares across TV news programs. Figure 2 compares these ITANES-based estimates against the actual, AUDITEL-based audience shares. Differently from Figure 1, this figure shows virtually no difference between self-reported and actual news choices across the six main channels. ${ }^{13}$

On the other hand, if we consider the total time spent watching television, self-reports in

of TV news 6 days a week, and about $6 \%$ watch every day. So, the difference with ITANES data is slightly less pronounced than what is shown in Figure 1, but still large.

${ }^{13}$ RAI 1 has the most-watched TV news program both according to AUDITEL viewership and ITANES self-reported preferences, closely followed by Mediaset 5 . RAI 3 is third, followed by RAI 2, Mediaset 6 and Mediaset 4. If anything, respondents slightly overstate their preference for RAI 1 and understate their preference for Mediaset 5 . These gaps might partially reflect individuals watching a second news show in addition to their favorite. 
surveys are systematically lower than actual viewing behavior. According to AUDITEL data, viewers watched on average 204 minutes of television per day in 2009, and 207 in 2010. In most of the available surveys, Italian respondents report that they watch an average of 2.5 and 3.5 hours of television per day. For example, in the Italian National Institute of Statistics (ISTAT) survey of 2010 on time-use, respondents report watching television 181 minutes per day, on average. The AUDITEL average for that year is $14.4 \%$ higher than the self-reports. As in the case of news consumption, these differences are likely due in part to social-desirability bias.

Table 1: Average Viewing Patterns

\begin{tabular}{|c|c|c|c|c|c|c|c|c|}
\hline Group & $\begin{array}{c}\text { Total } \\
\text { Minutes }\end{array}$ & $\begin{array}{l}\text { News } \\
\text { Minutes }\end{array}$ & $\begin{array}{l}\text { News } \\
\text { Share }\end{array}$ & $\begin{array}{l}\text { 1-6 Evening } \\
\text { News Minutes }\end{array}$ & $\begin{array}{l}\text { Share } \\
\text { Hard }\end{array}$ & $\begin{array}{l}\text { Share } \\
\text { Soft }\end{array}$ & $\begin{array}{c}\text { Share } \\
\text { Sensational }\end{array}$ & Obs. \\
\hline \multicolumn{9}{|l|}{ Education } \\
\hline Elementary or Less & 289 & 34 & 0.12 & 16 & 0.38 & 0.24 & 0.14 & 2737 \\
\hline Middle School & 239 & 25 & 0.10 & 11 & 0.36 & 0.25 & 0.13 & 3552 \\
\hline High School (Tech.) & 174 & 18 & 0.10 & 8 & 0.37 & 0.25 & 0.13 & 2270 \\
\hline High School (Acad.) & 181 & 19 & 0.10 & 8 & 0.36 & 0.25 & 0.13 & 4642 \\
\hline University & 149 & 16 & 0.11 & 7 & 0.37 & 0.26 & 0.12 & 2415 \\
\hline \multicolumn{9}{|l|}{ Income Group } \\
\hline Low & 206 & 20 & 0.10 & 9 & 0.36 & 0.25 & 0.13 & 1481 \\
\hline Middle & 215 & 23 & 0.11 & 10 & 0.36 & 0.25 & 0.13 & 9885 \\
\hline High & 189 & 21 & 0.11 & 10 & 0.38 & 0.24 & 0.13 & 4250 \\
\hline \multicolumn{9}{|l|}{ Social Class } \\
\hline Low & 241 & 25 & 0.10 & 12 & 0.36 & 0.25 & 0.13 & 5149 \\
\hline High & 190 & 21 & 0.11 & 9 & 0.37 & 0.25 & 0.13 & 10467 \\
\hline \multicolumn{9}{|l|}{ Gender } \\
\hline Male & 185 & 20 & 0.11 & 9 & 0.37 & 0.25 & 0.13 & 7280 \\
\hline Female & 227 & 24 & 0.11 & 11 & 0.37 & 0.25 & 0.13 & 8336 \\
\hline \multicolumn{9}{|l|}{ Age Group } \\
\hline $18-29$ & 106 & 8 & 0.09 & 4 & 0.34 & 0.27 & 0.12 & 2299 \\
\hline $30-39$ & 149 & 12 & 0.09 & 5 & 0.34 & 0.27 & 0.12 & 2627 \\
\hline $40-49$ & 179 & 16 & 0.09 & 8 & 0.35 & 0.26 & 0.13 & 3309 \\
\hline $50-59$ & 232 & 25 & 0.11 & 12 & 0.38 & 0.24 & 0.13 & 2357 \\
\hline $60-69$ & 283 & 35 & 0.13 & 15 & 0.40 & 0.23 & 0.14 & 2517 \\
\hline $70-79$ & 307 & 39 & 0.13 & 18 & 0.40 & 0.23 & 0.14 & 1730 \\
\hline $80-99$ & 276 & 36 & 0.14 & 18 & 0.40 & 0.22 & 0.14 & 777 \\
\hline
\end{tabular}

The AUDITEL data also show that the total time spent watching television is correlated with variables such as education, age, and gender. Table 1 reports a few summary statisticshere we focus on columns 1-3. Individuals with more education spend less time watching 


\section{Figure 3: Percentage of News Broadcast Watched, All Channels}

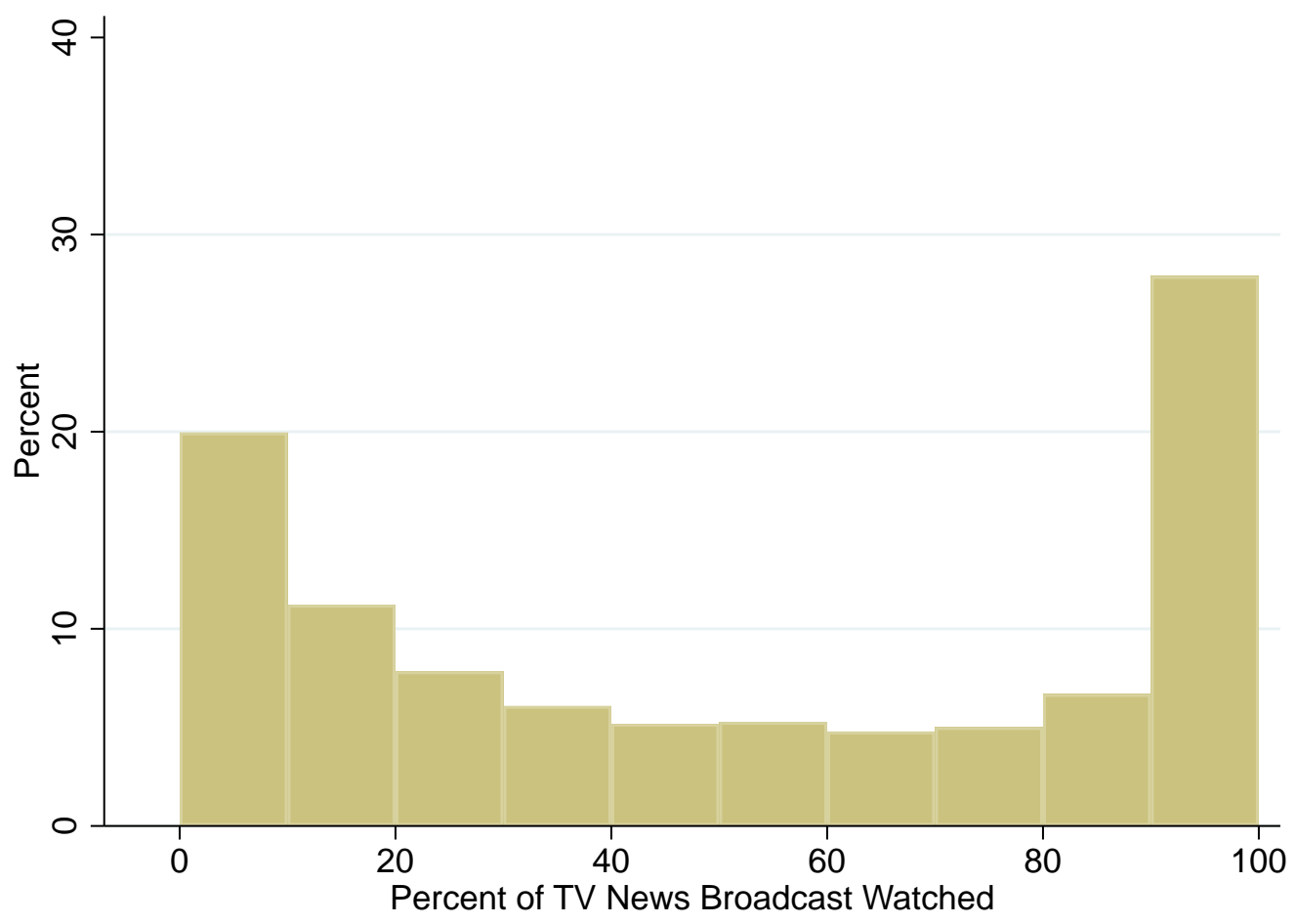

television while older people and women watch more (column 1). These patterns are similar when we focus instead on time spent watching television news (column 2). Individuals with less education watch more TV news on average than individuals with more education, and women watch slightly more TV news than men. In general, the people who watch more television overall also tend to watch more TV news. The time spent watching news as a share of the total time spent watching television (column 3 ) is broadly constant across subgroups, except for age. Elderly individuals not only watch more television than younger individuals, but they watch more minutes of TV news as a share of the total time spent watching.

Using the AUDITEL data we can also compute - for every evening TV news program each day - the percentage of the show watched by each individual. The distribution of these percentages is shown in Figure 3. The histogram is U-shaped, and highest for the right-most bin, i.e., for those cases where an individual watches over $90 \%$ of the program. We report the same graph separately for each individual channel in Figure A.1, in Appendix A.2. There is some 
variation across channels, in particular the spikes at the right-hand side of the distribution are higher for the programs that have more total viewers, i.e., RAI1, Mediaset 5 and RAI 3.

Table 2: Classification of Viewing Minutes

\begin{tabular}{|c|c|c|c|c|c|}
\hline \multirow[b]{2}{*}{ Channel } & \multicolumn{4}{|c|}{$\%$ of Minutes Where Viewer Is: } & \multirow{2}{*}{$\begin{array}{c}\text { Total } \\
\text { Minutes }\end{array}$} \\
\hline & Joining & Staying & Leaving & Surfing & \\
\hline 1 & 4.6 & 93.0 & 2.0 & 0.4 & $26,861,099$ \\
\hline 2 & 7.2 & 87.4 & 4.4 & 1.0 & $9,270,108$ \\
\hline 3 & 5.6 & 91.8 & 2.2 & 0.5 & $9,325,704$ \\
\hline 4 & 5.9 & 89.0 & 3.8 & 1.3 & $4,185,714$ \\
\hline 5 & 4.7 & 92.7 & 2.2 & 0.4 & $23,399,786$ \\
\hline 6 & 7.6 & 87.7 & 3.9 & 0.9 & $3,867,746$ \\
\hline All & 5.3 & 91.6 & 2.5 & 0.6 & $76,910,157$ \\
\hline
\end{tabular}

Finally, the AUDITEL data also allow us to classify - for each TV news program - the minutes spent that each individual spends "joining," "staying" on, or "leaving" the program. We can also detect "surfing," i.e., when an individual leaves a program in minute $t$ and rejoins in minute $t+1$. Summary statistics of these behaviors are displayed in Table 2. By far the most common behavior is "staying," which accounts for about $92 \%$ of all minutes. Thus, evidently there is a large amount of inertia in viewing. About $5 \%$ of total minutes involve "joining" and only $2.5 \%$ involve "leaving." Note that we define "leaving" as leaving before the show ends. So, although every viewer that watches a show must "join" it at some point, viewers who watch until the very end are not classified as "leaving" it. The percentage of "staying" minutes is somewhat larger for the TV news programs with the highest ratings, i.e., RAI 1, Mediaset 5 and RAI3. Conversely, the percentages of "leaving" minutes is smaller for these programs. ${ }^{14}$

\footnotetext{
${ }^{14}$ The AUDITEL data also allows us to track the dynamics of the audience for each TV news program. Figures A.2 and A.3 in Appendix A.2 show the raw number of individuals watching each broadcast - a minute-by-minute stock variable - together with the minute-by-minute flow of individuals leaving or joining that broadcast. For RAI 1 and Mediaset 5 the stock of viewers increases at a decreasing rate for the first 30 minutes and then decreases rapidly. For RAI 3 the stock of viewers increases continually throughout the show. The patterns for the other news programs are more mixed. Importantly, there are no spikes in "joining" behavior at any time during any of the shows (except at the start), suggesting that there is little or no anticipatory behavior. For example, it is not the case that a large number of individuals joins a show when the sports or weather segments typically begin.
} 


\subsection{The Osservatorio Data}

Recall that we want to study the real-time behavior of TV news viewers as a function of the type of content that is being shown. Are they more likely to switch away during a hard news story than a soft news story? To do this, we match AUDITEL data with a database of content provided by the Osservatorio di Pavia.

For each of the main evening news programs, the Osservatorio database contains the starting minute and ending minute of each news story in the program, a short summary of the story, and a classification of the main issue or issues covered in that story. The summaries and issue codes allow us to classify each story as "hard," "soft," or "sensational," or unclassified and left to a residual category. Broadly speaking, hard news stories are those covering international affairs, domestic politics, public policy issues, the economy, business, and so on. Soft news stories are those about sports, entertainment, celebrities, fashion, food, and so on. Sensational news stories are those about natural disasters, large accidents (e.g., deadly accidents in the workplace, not simple traffic accidents), and crime (e.g., grizzly murders, not crime as a policy issue). Appendix A.1 gives the details of the procedure we use to classify each news story.

During the two-year period under study, there were a total of 46,469 hard news stories, 29,126 soft news stories, and 32,063 sensational news stories. Some stories are in more than one category. For example, a story about a deadly workplace accident that also discusses lax government enforcement of safety regulations would be classified as both hard and sensational. A story about a prominent Italian politician declaring that he would not root for the national team during the World Cup would be classified as both hard and soft. During 2009-2010, 2,413 stories were classified as both hard and soft news, 5,814 stories were classified as both hard and sensational news, and 1,643 stories were classified as both sensational and soft news. ${ }^{15}$

Figure 4 shows the average relative share of hard, soft and sensational news appearing during each minute of each news show. The pattern is clear: news programs start predominantly with hard news, and then progressively shift towards softer news. There is a peak in the share of soft news around the 30th minute of a show, which is at or near the end of most programs. On

\footnotetext{
${ }^{15}$ Only 26 stories were classified as hard and sensational and soft news.
} 


\section{Figure 4: What's on the News?}

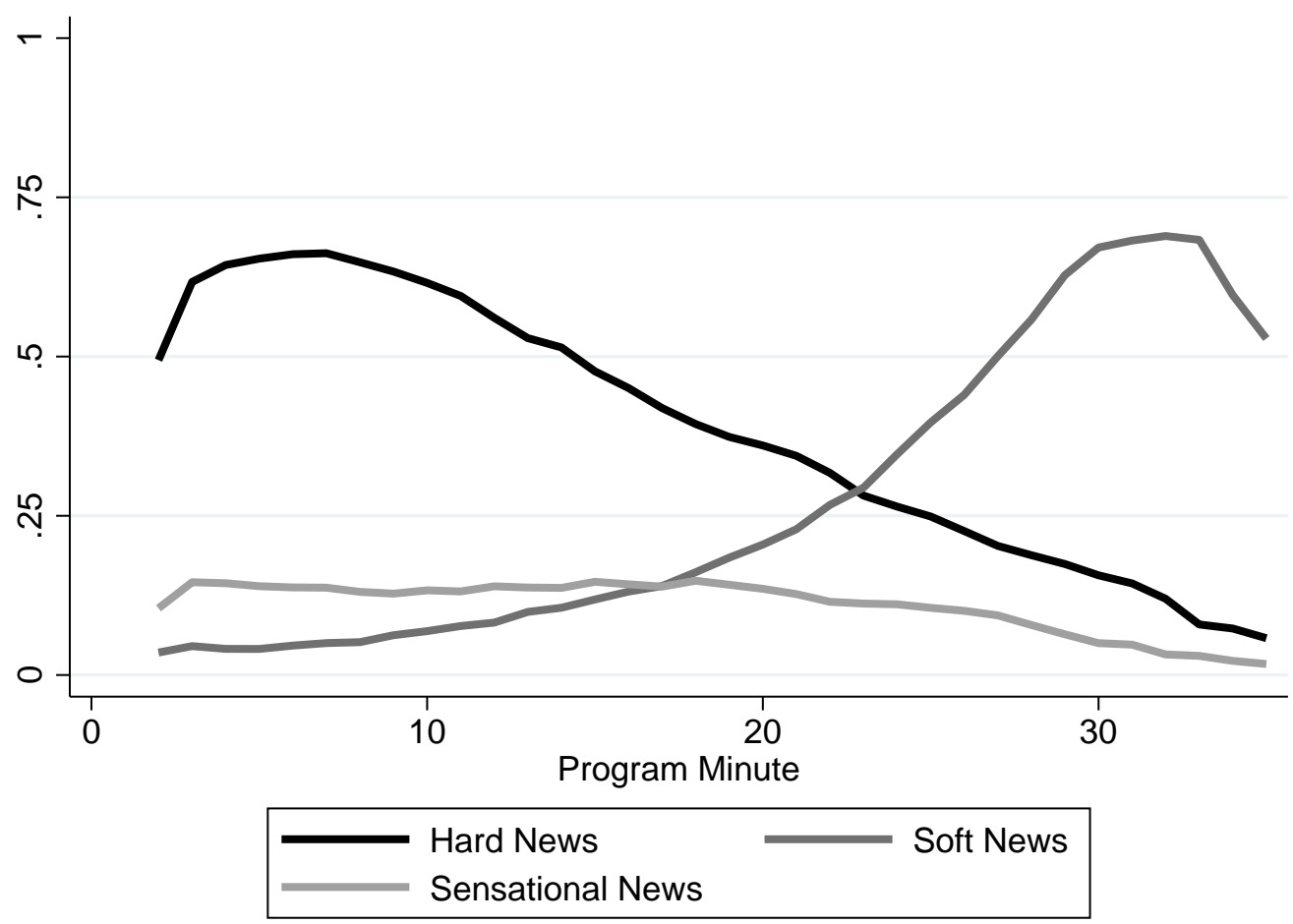

the other hand, sensational stories are distributed relatively uniformly over time. They are a bit more common than soft stories during the first half of the typical program, and then slowly decline during the second half. ${ }^{16}$

These patterns imply that it is important to know the exact time at which a viewer joins and leaves a show. Consider for example an individual who watches 15 minutes of a typical 30 minute news broadcast. If that person joins during the first 5 minutes, then he or she will be exposed to substantially more hard news than a person who joins in minute 15 . Therefore in the analysis below we are careful to investigate the heterogeneity of viewing behavior across different time segments of each show.

\footnotetext{
${ }^{16}$ Appendix Figure A.4 show how the patterns vary channel by channel. Overall, the shows tend to follow the same broad pattern, although with some differences, especially for RAI 3 and Mediaset 6.
} 


\section{$3 \quad$ Viewership By Type of News}

Here we present some basic facts about the relative amounts of hard, soft, and sensational news consumed, i.e., the "diet" of TV news viewers. ${ }^{17}$ Table 1 above shows the news diet as a function of individual socioeconomic characteristics. Column 4 reports the total number of evening news minutes watched by different subgroups, while columns 5-7 report the share of minutes spent watching hard, soft, and sensational news, respectively. Interestingly, there are almost no significant differences in the fraction of minutes spent watching hard, soft, and sensational news across subgroups, except for age. Hard news accounts for about 35-37\% of total news watched, and soft news accounts for about $25 \%$, irrespective of education, social class, income or gender. The one exception is that hard news consumption increases with age and soft news consumption decreases with age. Older individuals not only watch more news, but a larger share of the news they watch is hard news.

One reason these patterns are interesting is that they shed light on the role television news plays, or does not play, in helping to produce an informed citizenry. A stylized fact in the political science literature is that more educated and richer citizens are on average more informed about political matters than less educated and poorer ones. Also, men appear to be more informed about politics than women. There is less agreement about why this knowledge gap exists (Converse and Dupeux 1962, Tichenor et al. 1970, Delli Carpini and Keeter 1996). As noted in section 2.2, individuals with less education watch more minutes of television news than individuals with more education, women watch more than men, and the differences between low- and high-income individuals is negligible (column 3). Moreover, given the "proportionality" result discussed immediately above, there is no noticeable difference in the share of hard and soft news respondents watch as a function of education, income, social class or gender. As a

\footnotetext{
${ }^{17}$ It is tempting to compare TV news programs to dinners. As the host, you must serve vegetables - the hard news - to make a healthy meal, but you need a good dessert - the soft news - to keep some people at the table, and possibly to attract more diners in the first place. This could explain the increasing percentage of soft news (desserts) and decreasing percentage of hard news ("the vegetables") during each TV news broadcasts, as well as variation between different channels - e.g., lots of dessert on Mediaset 6 for young viewers. Following this metaphor, sensational news is analogous to not-so-healthy but delicious courses that can be served anytime during the dinner.
} 
result, individuals with less education are also exposed to more minutes of hard TV news than those with more education, on average. Similarly, on average women are exposed to more hard TV news than men, and the differences between high-income and low-income individuals are small.

This suggests that television news consumption cannot account for the knowledge gap between richer and poorer individuals, more- and less-educated citizens, and men and women. Instead, researchers should look elsewhere, such as other news sources - newspapers, magazines, books, the internet-differences in attention to and interest in politics, or differences in the ability to process information or recall facts.

On the other hand, the percentage of time spent watching TV news over the total time spent watching TV overall is an increasing function of age as it goes from $9 \%$ to $14 \%$ (bottom panel of Table 1). This finding is consistent with the idea that the elderly not only spend more time at home than young and middle-aged people, but they might also be significantly more interested in knowing "what happens in the world" thanks to TV news.

Although Table 1 reveals little systematic variation in the average shares of hard vs soft news consumption across key socioeconomic dimensions, with the exception of age, there is substantial variation across individuals. Figure 5 shows one type of variation: individuals who watch only a few minutes of the news programs that they watch tend to watch more soft news than in individuals who watch most of the show when they watch.

The x-axis in the figure shows the percentage of a TV news broadcast's total minutes each viewer watches, on average - for the shows they watch-binned by deciles (similar to Figure 3). The y-axis plots the "relative diet" consumed by the individuals in each decile. For hard news, for example, the values on the y-axis are calculated as follows. For each channel, we compute the total number of hard news minutes each individual watches on that channel over the entire sample period, divided by the total number of hard news minutes broadcast on that channel during the sample period. We then average these ratios across all 6 channels for each individual, and then average again over all individuals in the same decile along the x-axis. The values for soft and sensational news are calculated in the same way. Of course, for individuals 
who entirely or almost entirely watch the news show, the hard, soft, and sensational news consumptions bundle must correspond to the bundle aired by that TV news broadcast-i.e., they must all be approximately 1 . Figure 5 shows that individuals who tend to watch only short segments of news programs, e.g., only $20 \%$ or $30 \%$ of the entire show, tend to watch disproportionate amounts of soft news, and relatively less hard (and sensational) news. ${ }^{18,19}$

\section{Figure 5: Hard vs. Soft News "Diet" as a Function of Average Percentage of Broadcast Watched}

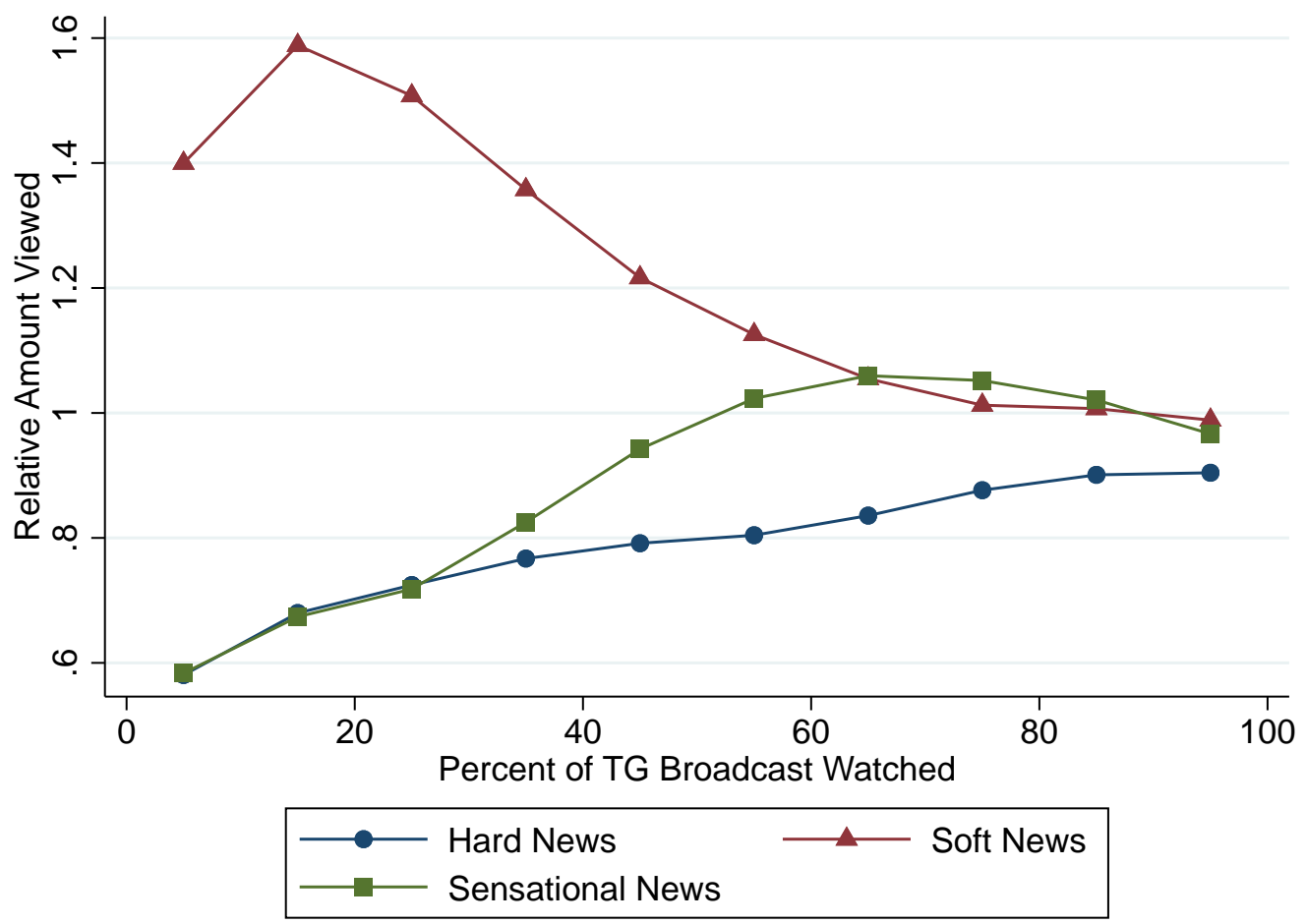

\footnotetext{
${ }^{18}$ Returning to "TV news as dinner" metaphor, this figure hints at an observable difference between consumers that properly eat their meat and vegetables - the hard news - and those who do not: the latter typically have shorter dinners than the former.

${ }^{19}$ Another implication is the following. While the initial quote by "the Teacher" from Pink Floyd's Another Brick in the Wall (Part 2) is about coercion ("If you don't eat yer meat, you can't have any pudding"), the data shown in Figure 5 refer instead to free individual choices. So, while the soft-news pudding might induce some marginal viewers to consume some hard-news meat (and vegetables), but not all of the available meat, as many viewers appear to choose short dinners with plenty of pudding.
} 


\section{Switching Behavior By Type of News}

In this section we study the switching behavior of news viewers. More specifically, we want to estimate the degree to which viewers appear to avoid hard news, switching to another channel (or turning off their TV) more when exposed to such stories; and whether they appear to be more attracted to, and therefore keep watching, soft news stories. We also explore the degree to which viewers appear to be attracted by sensational stories.

Note that the first choice viewers make is which channel to watch, and the data indicate that those who watch news do not choose to maximize the amount of soft news relative to hard news - otherwise, they could all watch Mediaset 6, which on average shows 11.1 minutes of soft news per show compared to just 4.8 minutes of hard news. This is true even within time-slot. The news programs on RAI 3 and Mediaset 4 both begin at 7:00 pm. RAI 3 airs 18.0 minutes of hard news and 3.9 minutes of soft news, on average, while for Mediaset 4 the corresponding figures are 13.7 and 10.2 minutes. If viewers simply sought less hard news, then they could all watch Mediaset 4. But they do not, and in fact RAI 3's news program has more than double the audience of Mediaset 4's. ${ }^{20}$ Similarly, RAI 1 and Mediaset 5 both begin at 8:00 pm. RAI 1 airs 14.8 minutes of hard news and 8.2 minutes of soft news per show, on average, while Mediaset 5 airs 11.0 minutes of hard news and 8.4 minutes of soft news. If viewers simply sought less hard news, then they could all watch Mediaset 5. However, they do not-in fact, RAI 1's news program has a slightly higher audience Mediaset 5's. ${ }^{21}$

Simple means of switching behavior are also suggestive. Averaging over all viewers, channels and news minutes, $1.97 \%$ of the audience switches away during hard news stories, while $4.2 \%$ switch away during soft news stories. Only $1.70 \%$ of viewers switch away during sensational news stories.

As shown by Figure 4 (and Figure A.4 in Appendix A.2), the balance of hard and soft

\footnotetext{
${ }^{20}$ Other factors could of course play some role in this choice, e.g., the marked difference in political leaning between RAI 3 and Mediaset 4. Still, this revealed preference argument rules out a simple lexicographic model of choice, according to which only the hard versus soft balance of news matters in decisions about TV news watching.

${ }^{21}$ In the choice between RAI 1 and Mediaset 5 , the difference in the ideological leaning is narrower than in the previous case of RAI 3 versus Mediaset 4 .
} 
news varies over the course of each news program. Therefore, in our empirical specifications we treat each 5-minute block within each TV news show separately. For each 5-minute block we therefore estimate the following model

$$
\text { Switch }_{i t}=\gamma_{j}+\theta_{t}+\beta_{1} \text { Hard News }_{i t}+\beta_{2} \text { Soft News }_{i t}+\beta_{3} \text { Sensational News }_{i t}+\epsilon_{i t}
$$

where $i$ is an index for the individual viewer, $j$ is an index for the news program (channel), and $t$ is an index for the minute within each block. Each observation is for a given viewer $i$ at minute $t$, watching a given news program $j$ (since each viewer can only watch one channel at a time, we include only the $i$ and $t$ subscripts in describing the observations). The independent variables are indicators: Hard News $i t=1$ if the news story $i$ is watching at time $t$ is a hard news story and zero otherwise; Soft $N e w s_{i t}=1$ if the news story $i$ is watching at time $t$ is a soft news story and zero otherwise; Sensational News $s_{i t}=1$ if the news story $i$ is watching at time $t$ is a sensational news story and zero otherwise. The omitted category is a collection of miscellaneous stories which are not easily classified as hard, soft, or sensational. ${ }^{22}$ The term $\gamma_{j}$ denotes a channel-specific fixed effect, while $\theta_{t}$ denotes an elapsed-time fixed effect, i.e., we allow the average propensity to switch off to vary for each minute within each separate block. Standard errors are clustered by individual viewer in all regressions.

Recall from Table 2 that only about $2.5 \%$ of all minutes of TV news viewing involve switching. Therefore, to avoid regression coefficients with many zeroes, we define the dependent variable as follows: Switch $i t=100$ if viewer $i$ switches away from the channel he or she is watching sometime during minute $t$, and zero otherwise. This implies that we can interpret an estimated coefficient $\hat{\beta}_{1}$ of 1.0 as a one percentage point increase in the probability of switching during a hard news story relative to the omitted category of unclassified stories.

The first choice TV news viewers make is which program to watch. Hence, we first estimate models that do not include the channel-specific fixed effects $\left(\gamma_{j}\right)$. This provides us with estimates of the overall propensity to switch away from hard versus soft news block-by-block, including the decision to watch the news on one channel rather than another.

\footnotetext{
${ }^{22}$ As noted above, the "standard" length of a news broadcast varies across stations. The overall median is 33 minutes, and the mean is about 34 minutes. In the regressions we drop observations that occur after the first 35 minutes of a broadcast.
} 


\section{Figure 6: Propensity to Switch from Soft News Relative to Hard or Sensational News, By Block, Without Channel-Specific Fixed Effects}
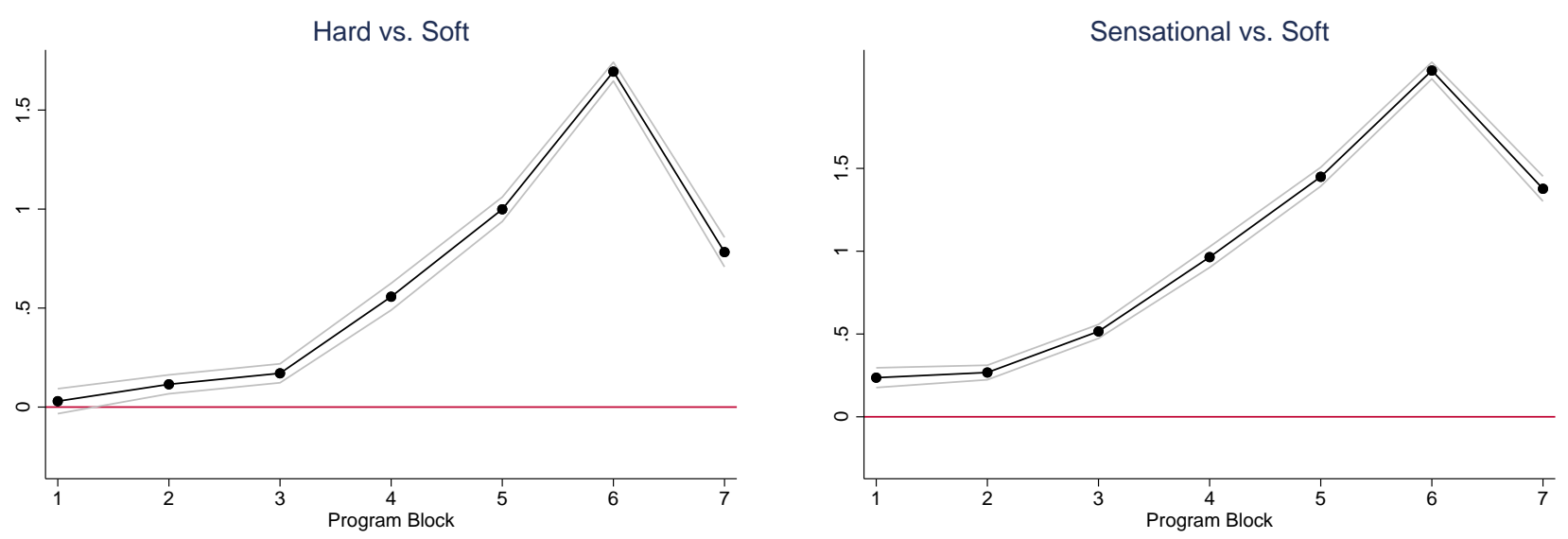

If viewers are more likely to switch off from the TV news they are watching when Hard News= 1 compared to when Soft News $=1$, then $\beta_{1}>\beta_{2}$. If the opposite is true, then $\beta_{2}>\beta_{1}$. Thus, for each block we compute the difference in the point estimates, $\hat{\beta}_{2}-\hat{\beta}_{1}$, as well the $95 \%$ confidence interval around the estimated difference.

The results are presented in the left panel of Figure 6. The black curve shows the point estimate of the difference, $\hat{\beta}_{2}-\hat{\beta}_{1}$, block by block. The light gray lines show the $95 \%$ confidence interval around each point estimate.

For all 5-minute blocks except the first, $\hat{\beta}_{2}-\hat{\beta}_{1}$ is positive and statistically significant. That is, viewers are significantly more likely to switch during a Soft News story than during a Hard News story. Moreover, this difference is steadily increasing as time goes by, reaching a peak in block $6 .^{23}$ This is inconsistent with the simple hypothesis that TV consumers always seek entertainment rather than politically relevant information. ${ }^{24}$

We can also compare the propensity to switch away from soft news with the propensity to switch away from sensational news, by studying the block-by-block estimates of $\hat{\beta}_{2}-\hat{\beta}_{3}$. These

\footnotetext{
${ }^{23}$ We do not pay much attention to the relative drop between blocks 6 and 7 , since only the news shows on RAI 1, Mediaset 4 and Mediaset 5 are long enough to regularly have block 7 .

${ }^{24}$ It is likely that the switching behavior of viewers depends both on what they are currently watching and on their expectations about what can be found on other channels (as well as non-TV options).
} 
are shown in the right-hand side panel of Figure 6. Again, the black curve shows the point estimate of $\hat{\beta}_{2}-\hat{\beta}_{3}$, while the light gray lines show the $95 \%$ confidence intervals. In this case, for all 5-minute blocks, $\hat{\beta}_{2}-\hat{\beta}_{3}$ is positive and statistically significant. That is, viewers are significantly more likely to switch during a Soft News story than during a Sensational News story. Similar to the case of soft vs. hard news, the difference increases over time, and reaches a peak in block 6 .

Comparing the two panels of Figure 6 , we see that $\hat{\beta}_{2}-\hat{\beta}_{3}>\hat{\beta}_{2}-\hat{\beta}_{1}$ for all blocks, which implies that $\hat{\beta}_{1}-\hat{\beta}_{3}>0$. That is, the propensity to switch off during Sensational News stories is systematically lower than during Hard News stories.

Table 3 presents the full regression results underlying Figure 6. Each column shows a different 5-minute block, and the rows at the bottom show the p-values of the F-tests for the null hypotheses $\hat{\beta}_{2}-\hat{\beta}_{1}=0, \hat{\beta}_{2}-\hat{\beta}_{3}=0$, and $\hat{\beta}_{1}-\hat{\beta}_{3}=0$.

Table 3: Viewer Switching Behavior, All Channels Pooled, No Channel-Specific Fixed Effects $(\mathrm{DV}=$ Percent of Time Viewer Switched Away From Channel)

\begin{tabular}{|c|c|c|c|c|c|c|c|}
\hline \multirow{2}{*}{ Variable } & \multicolumn{7}{|c|}{ Block } \\
\hline & 1 & 2 & 3 & 4 & 5 & 6 & 7 \\
\hline \multirow[t]{2}{*}{ Soft News } & -0.008 & 0.102 & 0.243 & 0.602 & 1.003 & 1.506 & 1.257 \\
\hline & $(0.030)$ & $(0.021)$ & $(0.021)$ & $(0.029)$ & $(0.025)$ & $(0.020)$ & $(0.027)$ \\
\hline \multirow{2}{*}{ Hard News } & -0.038 & -0.013 & 0.072 & 0.044 & 0.004 & -0.188 & 0.474 \\
\hline & $(0.018)$ & $(0.013)$ & $(0.012)$ & $(0.014)$ & $(0.014)$ & $(0.015)$ & $(0.036)$ \\
\hline \multirow[t]{2}{*}{ Sensational News } & -0.245 & -0.166 & -0.273 & -0.362 & -0.446 & -0.585 & -0.120 \\
\hline & $(0.015)$ & $(0.013)$ & $(0.012)$ & $(0.012)$ & $(0.011)$ & $(0.015)$ & $(0.036)$ \\
\hline Observations & $7,701,954$ & $10,695,172$ & $11,230,997$ & $11,778,734$ & $12,122,955$ & $11,622,801$ & $6,765,630$ \\
\hline p-value 1 & 0.354 & 0.000 & 0.000 & 0.000 & 0.000 & 0.000 & 0.000 \\
\hline p-value 2 & 0.000 & 0.000 & 0.000 & 0.000 & 0.000 & 0.000 & 0.000 \\
\hline p-value 3 & 0.000 & 0.000 & 0.000 & 0.000 & 0.000 & 0.000 & 0.000 \\
\hline
\end{tabular}

Fixed effects for each program minute included in all specifications. Standard errors, clustered by individual, are in parentheses. p-value 1 is for F-test of H0: Soft News $=$ Hard News $\left(\beta_{2}=\beta_{1}\right)$. p-value 2 is for F-test of H0: Soft News $=$ Sensational News $\left(\beta_{2}=\beta_{3}\right)$. p-value 3 is for F-test of H0: Hard News $=$ Sensational News $\left(\beta_{1}=\beta_{3}\right)$.

In relative terms, the differences in average switching behavior across the different types of news stories are substantively large. Consider for example the difference in switching from a hard news story versus a soft news story in block 4. In block 4, on average 1.90 percent of viewers switched away while watching the news - 1.99 percent switched away while watching 


\section{Figure 7: Propensity to Switch from Soft News Relative to Hard or Sensational News, By Block, With Channel-Specific Fixed Effects}
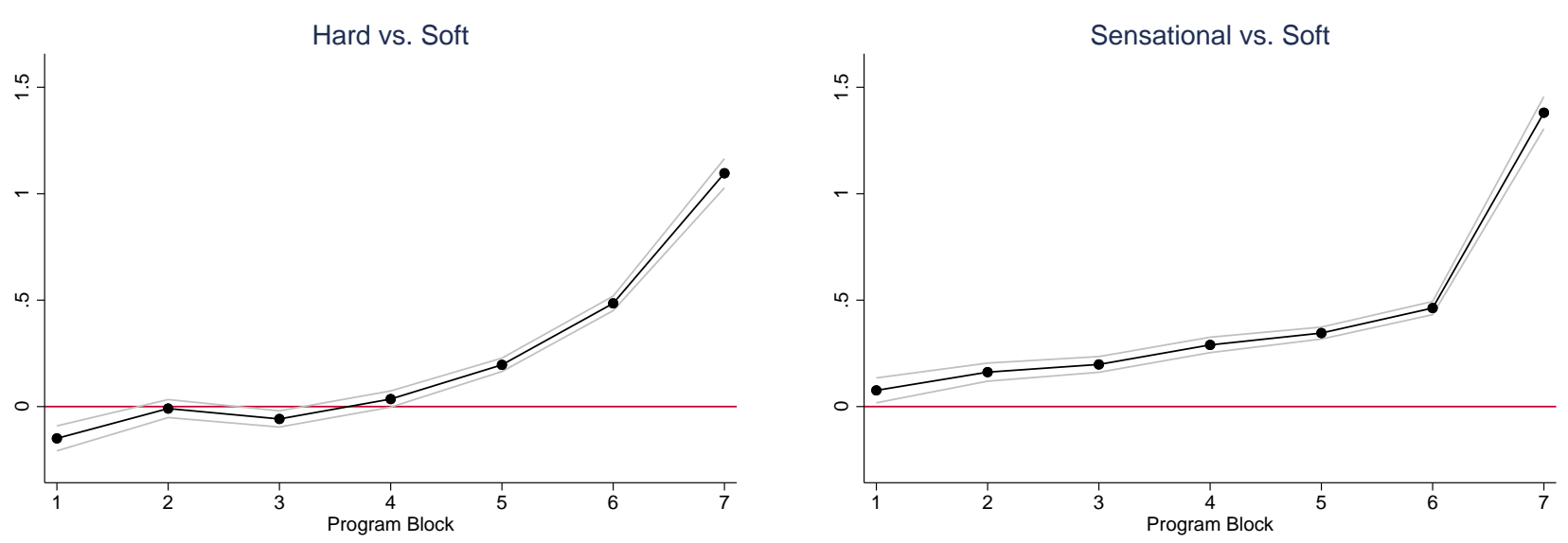

a hard news story, while 2.56 percent did so during a soft news story. Not surprisingly, the difference, $2.56-1.99=0.57$, is almost the same as the point estimate of $\hat{\beta}_{2}-\hat{\beta}_{1}$ for block 4 , which is 0.56 . The point estimate of the difference from the regression implies that, on average, during block 4 a viewer is about $28 \%$ more likely to switch away from a soft news story than a hard news story. The estimated differences are even larger in blocks 5, 6, and 7 .

We now include channel-specific fixed effects $\left(\gamma_{j}\right)$. This yields estimates of the withinchannel behavior, i.e., viewers' decisions to switch conditional on having chosen to watch a given news program. The results are shown in Figure 7, and the full regression results underlying the figure are presented in Table 4. Analogously to Figure 6, the differences between hard and soft news are presented on the left, while those comparing sensational and soft are shown on the right.

With the channel fixed effects included, the differences in switching behavior when watching hard versus soft news are generally smaller than those estimated without channel fixed effects. In block $1, \hat{\beta}_{2}-\hat{\beta}_{1}$ is slightly negative and statistically significant. That is, viewers are significantly more likely to switch during a Hard News story than during a Soft News story. In blocks 2,3 and $4, \hat{\beta}_{2}-\hat{\beta}_{1}$ is approximately zero, so viewers were equally likely to switch away during hard and soft news stories. In blocks, 5,6 , and $7, \hat{\beta}_{2}-\hat{\beta}_{1}$ is positive and statistically significant, 
implying that viewers are significantly more likely to switch during a Soft News story than during a Hard News story. The difference between $\hat{\beta}_{2}$ and $\hat{\beta}_{1}$ is large in blocks 6 and 7 . The pattern is again inconsistent with the simple hard news avoidance hypothesis. ${ }^{25}$

We can also compare the propensity to switch away from soft news with the propensity to switch away from sensational news, by studying the block-by-block estimates of $\hat{\beta}_{2}-\hat{\beta}_{3}$. In this case, for all 5 -minute blocks, $\hat{\beta}_{2}-\hat{\beta}_{3}$ is positive and statistically significant. That is, viewers are significantly more likely to switch during a Soft News story than during a Sensational News story, and the difference increases steadily over time.

Comparing the two panels of Figure 7 , we see again that $\hat{\beta}_{2}-\hat{\beta}_{3}>\hat{\beta}_{2}-\hat{\beta}_{1}$ for most blocks, so $\hat{\beta}_{1}-\hat{\beta}_{3}>0$. That is, the propensity to switch off during Sensational News stories is systematically smaller than during Hard News stories. This suggests that television news directors and producers would prefer to air more sensational news stories, if they could. However, news directors do not control the supply of sensational news. Moreover, if the stories in this category became commonplace - natural disasters or large industrial accidents every day - they would no longer be "sensational." 26 . This way, viewers never know when a sensational story might be coming, and some viewers might keep watching just in case one will appear soon.

In relative terms, the differences in average switching behavior across the different types of news stories are substantively large in the last two blocks. Consider for example the difference in switching from a hard news story versus a soft news story in block 6 . In this block, on average $2.55 \%$ of viewers switched away while watching a hard news story. The estimated difference $\hat{\beta}_{2}-\hat{\beta}_{1}$ from the regression, 0.49, implies that on average, during block 6 a viewer is about $19 \%$ more likely to switch away from a soft news story than a hard news story.

Appendix Table A.3 reports results analogous to those in Table 4 separately for each channel. There we observe some interesting heterogeneity across channels. Mediaset 6, which is geared toward a younger audience, stands as an outlier vis-a-vis the other channels. Its viewers are more likely to switch away during hard news stories than during soft news stories in every block

\footnotetext{
${ }^{25}$ It is likely that the switching behavior of viewers depends both on what they are currently watching and on their expectations about what can be found on other channels (as well as non-TV options).

${ }^{26}$ Thus, the best the news director can do is place them strategically during the show. Perhaps this why they are spread relatively uniformly, as shown in Figure 4
} 
Table 4: Viewer Switching Behavior, All Channels Pooled, With Channel-Specific Fixed Effects (DV = Percent of Time Viewer Switched Away From Channel)

\begin{tabular}{lccccccc}
\hline \hline & & \multicolumn{7}{c}{ Block } & & & \\
Variable & 1 & 2 & 3 & 4 & 5 & 6 & 7 \\
\hline Soft News & -0.106 & 0.101 & 0.058 & 0.138 & 0.219 & 0.342 & 1.112 \\
& $(0.031)$ & $(0.021)$ & $(0.018)$ & $(0.017)$ & $(0.014)$ & $(0.013)$ & $(0.025)$ \\
Hard News & 0.043 & 0.110 & 0.116 & 0.102 & 0.023 & -0.143 & 0.016 \\
& $(0.014)$ & $(0.012)$ & $(0.011)$ & $(0.011)$ & $(0.011)$ & $(0.013)$ & $(0.030)$ \\
Sensational News & -0.183 & -0.061 & -0.140 & -0.152 & -0.126 & -0.121 & -0.268 \\
& $(0.015)$ & $(0.012)$ & $(0.011)$ & $(0.010)$ & $(0.010)$ & $(0.013)$ & $(0.035)$ \\
Observations & $7,701,954$ & $10,695,172$ & $11,230,997$ & $11,778,734$ & $12,122,955$ & $11,622,801$ & $6,765,630$ \\
\hline p-value 1 & 0.000 & 0.670 & 0.003 & 0.068 & 0.000 & 0.000 & 0.000 \\
p-value 2 & 0.011 & 0.000 & 0.000 & 0.000 & 0.000 & 0.000 & 0.000 \\
p-value 3 & 0.000 & 0.000 & 0.000 & 0.000 & 0.000 & 0.168 & 0.000 \\
\hline
\end{tabular}

Fixed effects for channel and program minute included in all specifications. Standard errors, clustered by individual, are in parentheses. p-value 1 is for F-test of H0: Soft News $=$ Hard News $\left(\beta_{2}=\beta_{1}\right)$. p-value 2 is for F-test of H0: Soft News $=$ Sensational News $\left(\beta_{2}=\beta_{3}\right)$. p-value 3 is for F-test of H0: Hard News $=$ Sensational News $\left(\beta_{1}=\beta_{3}\right)$.

except block 2 (where the difference is small and statistically insignificant). ${ }^{27}$

Since we have individual level data we can also study whether different types of viewers respond differently to hard and soft news. Figure 8 compares men and women, and Figure 9 shows the differences by age. As in the previous figures, the block-by-block differences in the propensity to switch away from soft versus hard news are shown on the left, and the analogous differences for soft versus sensational news are presented on the right. The full regression results are shown in Table A.1 and Table A.2 in Appendix A.2.

The patterns across blocks are basically the same for men and women. However, for all blocks, the point estimate of $\hat{\beta}_{2}-\hat{\beta}_{1}$ is larger for men than for women, meaning that men are relatively more likely to switch away from a Soft News story than a Hard News story, compared to women. In 4 of the 7 blocks the difference is statistically significant at the 0.05 level. When comparing Soft News with Sensational News, there are essentially no differences between men and women in blocks $1-4$. The difference in $\hat{\beta}_{2}-\hat{\beta}_{3}$ between men and women is positive and

\footnotetext{
${ }^{27}$ Interestingly, the largest difference in switching behavior when watching a soft news story versus when watching a hard news story (about 1.75) occurs in the last block of RAI2. Since the RAI 2 news show is the latest to start (at 8:30pm), viewers might simply switch away with such a high propensity as they want to watch - say - a movie on another channel, and there is only non-relevant soft news on the TV program itself (and it is almost 9pm).
} 
Figure 8: Propensity to Switch from Soft News

Relative to Hard or Sensational News, By Gender and Block
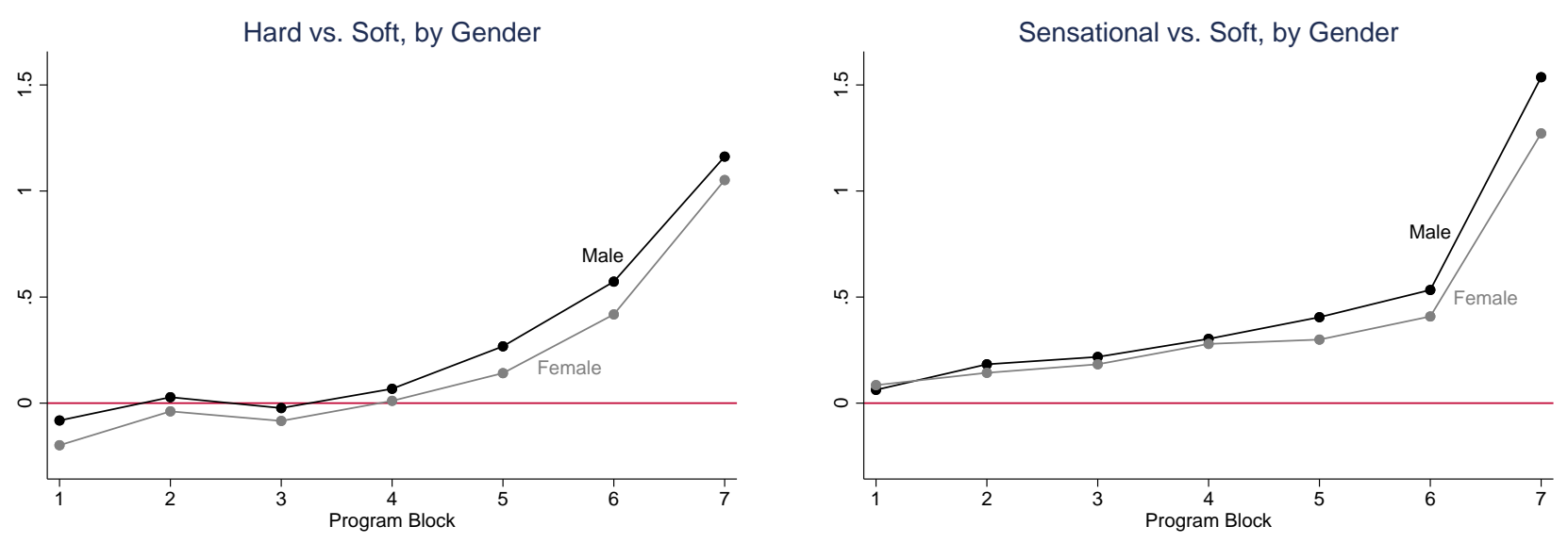

statistically significant at the 0.05 level in blocks 5-7. Thus, during these blocks, men are somewhat more likely to switch away from a Sensational News story than a Hard News story, compared to women.

The patterns across age groups are also interesting, as shown in Figure 9. We divide viewers in three age groups: "young" (15-39), "middle-aged" (40-64) and "old" (65-99). Looking first at the panel on the left, we see almost no differences by age in blocks 1 and 2. Beginning in block 3, we see systematic differences in switching behavior between the old and young. Older viewers are more likely to switch off during Soft News than during Hard News, compared to younger viewers.

\section{Concluding Remarks}

Political observers in virtually all democratic countries complain about the electorate's lack of knowledge and information. Some blame the news media environment for this situation, arguing that there is too much soft news and not enough informative news, especially on television news broadcasts. Standard economic models would imply that media outlets seeking to maximize market share or profits must provide viewers with what they want. If they are providing soft news, it is because viewers demand it. 


\section{Figure 9: Propensity to Switch from Soft News Relative to Hard or Sensational News, By Age and Block}
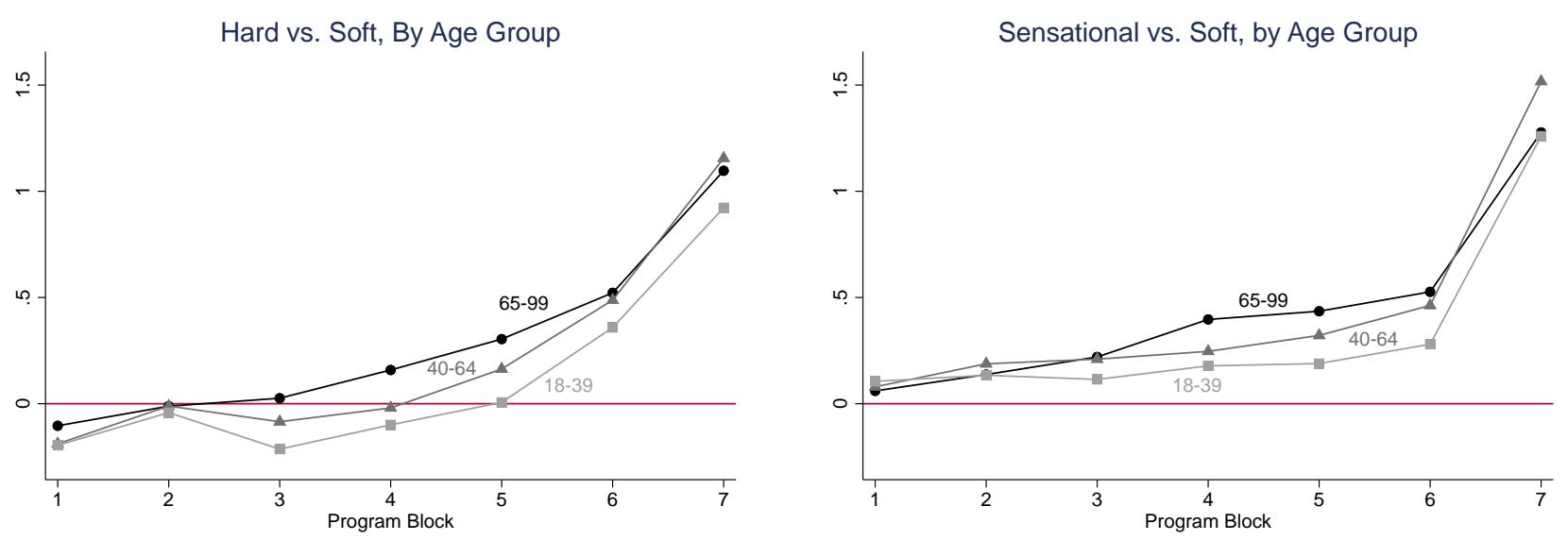

In this paper we have analyzed television news-watching behavior in Italy, exploiting two rich and fine-grained data sets that allow us to study actual viewer behavior, and to know what type of news story each viewer is watching, minute by minute, for an entire two-year period (2009-2010). We find that on average news programs broadcast many more hard news stories than soft news stories, and in fact the programs begin with mainly hard news. Also, those who watch the news do not all gravitate towards shows that broadcast the most amount of soft news. Most tellingly, we find no evidence that viewers are more likely to switch away during hard news stories than during soft news stories; in fact, if anything the opposite is true. Thus, the evidence is inconsistent with the simple hypothesis that there is a general tendency by all viewers to seek entertainment even while watching the news.

We have presented a variety of descriptive patterns and also individual-level regression analyses. The regressions focus on the difference in the propensity to switch away during a hard news story than during a soft news story. When not including channel-specific fixed effects, i.e., when looking at the overall variation in switching behavior between and within TV news stories, we find-perhaps surprisingly — that the propensity to switch away during a soft news story is systematically higher than during a hard news story, except during the first 5-minute block. Moreover, this difference in the propensity to switch away increases steadily as 
the news program proceeds. We find an even stronger difference to switch away during a soft news story than during a sensational story.

When we include channel-specific fixed effects in the regressions, and exploit only the variation within programs, the differences in switching behavior when watching hard versus soft news are generally smaller than those estimated without channel fixed effects, and generally statistically insignificant for the first half of the news program. However, they are still significant and sizable in the last 10-15 minutes of the show.

We also investigate some of the possible heterogeneity in the decision to switch off across different types of viewers. We also find significant differences in the propensity to switch away during hard versus soft news according to the gender and age of the viewer, and the specific TV news show the viewer watches. We find that young viewers are relatively more likely to switch away from hard news compared to older viewers, and in one of the five-minute blocks the young are significantly more likely to switch away from hard news than soft news stories.

In future work we will exploit the AUDITEL and Osservatorio data to study other aspects of news viewing behavior. The individual-level AUDITEL data allows us to study the viewers' decisions to switch away as a function of their viewing habits, i.e., on the basis of their revealed preferences minute by minute. For example, we can check whether habitual versus casual viewers of TV news programs are significantly different in their propensity to switch away during hard versus soft versus sensational news. We could also study how the quasi-random case of viewers happening to watch a very salient event on a TV news broadcast or during a "breaking news" program could affect systematically their viewing behavior in the short or in the medium/long run.

Finally, we plan to study the decision to switch on a given news broadcast. From an informational viewpoint, the "joining" behavior is trickier than the "leaving" behavior, since viewers do not know with certainty what they will find on the channel to which they switch to, while they know for sure what they decide not to watch anymore when leaving the channel. 


\section{References}

Baum, Matthew A. 2003. Soft News Goes to War: Public Opinion and American Foreign Policy in the New Media Age. Princeton, Princeton University Press.

Baum, Matthew A. and Angela S. Jamison. 2006. "The Oprah Effect: How Soft News Helps Inattentive Citizens Vote Consistently" Journal of Politics. 68 (4): 946-959.

Bertrand, Marianne and Sendhil Mullainathan. 2001. "Do People Mean What They Say? Implications for Subjective Survey Data." American Economic Review 91, 67-72.

Converse, Philip E., and Georges Dupeux. 1962. "Politicization of the Electorate in France and the United States." Public Opinion Quarterly 26(1): 1-23.

Delli Carpini, Michael X., and Scott Keeter (1996). What Americans Know About Politics and Why It Matters. Yale, Yale University Press.

Hamilton, James. 2004. All the News That's Fit to Sell: How the Market Transforms Information into News. Princeton, Princeton University Press.

McFadden, Daniel L., Bemmor, A.C., Caro, F.G., Dominitz, J., Jun, B., Lewbel, A., Matzkin, R.L., Molinari, F., Schwarz, N., Willis, R.J., Winter, J.K.. 2005. "Statistical Analysis of Choice Experiments and Surveys." Marketing Letters 16: 183-196.

Patterson, Thomas E. (2000). Doing Well and Doing Good: How Soft News Are Shrinking the News Audience and Weakening Democracy. Cambridge, Harvard University Press.

Prat, Andrea and David Stromberg. 2005. "Commercial Television and Voter Information". CEPR Discussion paper 4989

Prior, Marcus (2003). "Any Good News in Soft News? The Impact of Soft News Preference on Political Knowledge." Political Communication. 20: 149-171.

Prior, Markus. 2009. "The Immensely Inflated News Audience: Assessing Bias in SelfReported News Exposure." Public Opinion Quarterly 73(1): 130-143.

Reinemann, Carsten, Stanyer, J., Scherr, S., Legnante, G. 2011. "Hard and Soft News: A Review of Concepts, Operationalizations and Key Findings." Journalism 13 (2): 221-239.

Tichenor, Phillip J., George A. Donohue, and Clarice N. Olien. 1970. "Mass Media Flow and Differential Growth in Knowledge." Public Opinion Quarterly 34(2): 159-170.

Zaller, John (1999). "Market Competition and News Quality," UCLA working paper 


\section{A Appendix}

\section{A.1 Classification of News Stories as Hard, Soft and Sensational}

To classify TV news stories as hard, soft or sensational we proceed in steps. We first exploit the two broadest classifications by topic that the Osservatorio di Pavia performs on its dataset, and code as Hard News the stories that belong to the following topics: "cooperation and development" (cooperazione e sviluppo), "rights" (diritti), "business/entrepreneurship" (imprenditoria), "labor" (lavoro), "economic policies and policymaking" (politiche economiche), " "domestic politics" (politica interna), "statistics" (statistiche), "welfare and social policy" (welfare), "the economy" (economia), "foreign policy" (politica estera), "politics and government" (politica e governo), "immigration" (migrazioni), "organized crime" (criminalità organizzata), "war and terrorism" (guerra e terrorismo). ${ }^{28}$ Moreover, if the summary of the news story mentions (i) an Italian political party or (ii) politics-related terms or (iii) law-related terms, then we code that story as Hard News. The Italian political parties under consideration are: Alleanza Nazionale, Forza Italia, Lega Nord, Partito Democratico, Popolo delle Libertà. The politicsrelated terms are: "government" (governo), "minister" (ministro), "ministry (ministero), and "mayor" (sindaco). The law-related terms are "law" (legge) and "reform" (riforma).

We code a story as Soft News if-according to the two broadest topic classifications employed by the Osservatorio di Pavia - that story is about one of the following topics: "sports" (sport), "lifestyles and habits" (costume), "culture and cultural events" (cultura), "curiosities" (curiosità), "celebrities" (VIP), "weather report" (meteo), "other news" (altre notizie). We additionally code a story as Soft News if the words "sales/discounts" (saldi), "weather" (meteo) or "TV license" (canone RAI) appear in that story's summary. Finally, when the topic of the story is transport and infrastructure (trasporti e infrastrutture) or "nature and environment" (ambiente e natura) and the word "traffic" (traffico) appears in the story's description we classify that story as Soft News - these are typically stories about traffic jams.

Sensational News include stories about crime, serious accidents, and natural disasters. Thus,

\footnotetext{
${ }^{28}$ For reference, the two broadest classification fields in the Osservatorio dataset are called desc_midi_prim and desc_midi_sec.
} 
we code a story as "sensational" if - according to the two broadest classifications provided by the Osservatorio - that story is about "crime" (criminalità), "attacks on women and minors" (violenze su donne e minori), "accidents" (incidenti) and "disasters" (disastri). Note that stories about organized crime are coded as Hard News rather than Sensational News, because these have important implications for assessing government performance.

\section{A.2 Supplemental Figures and Tables}




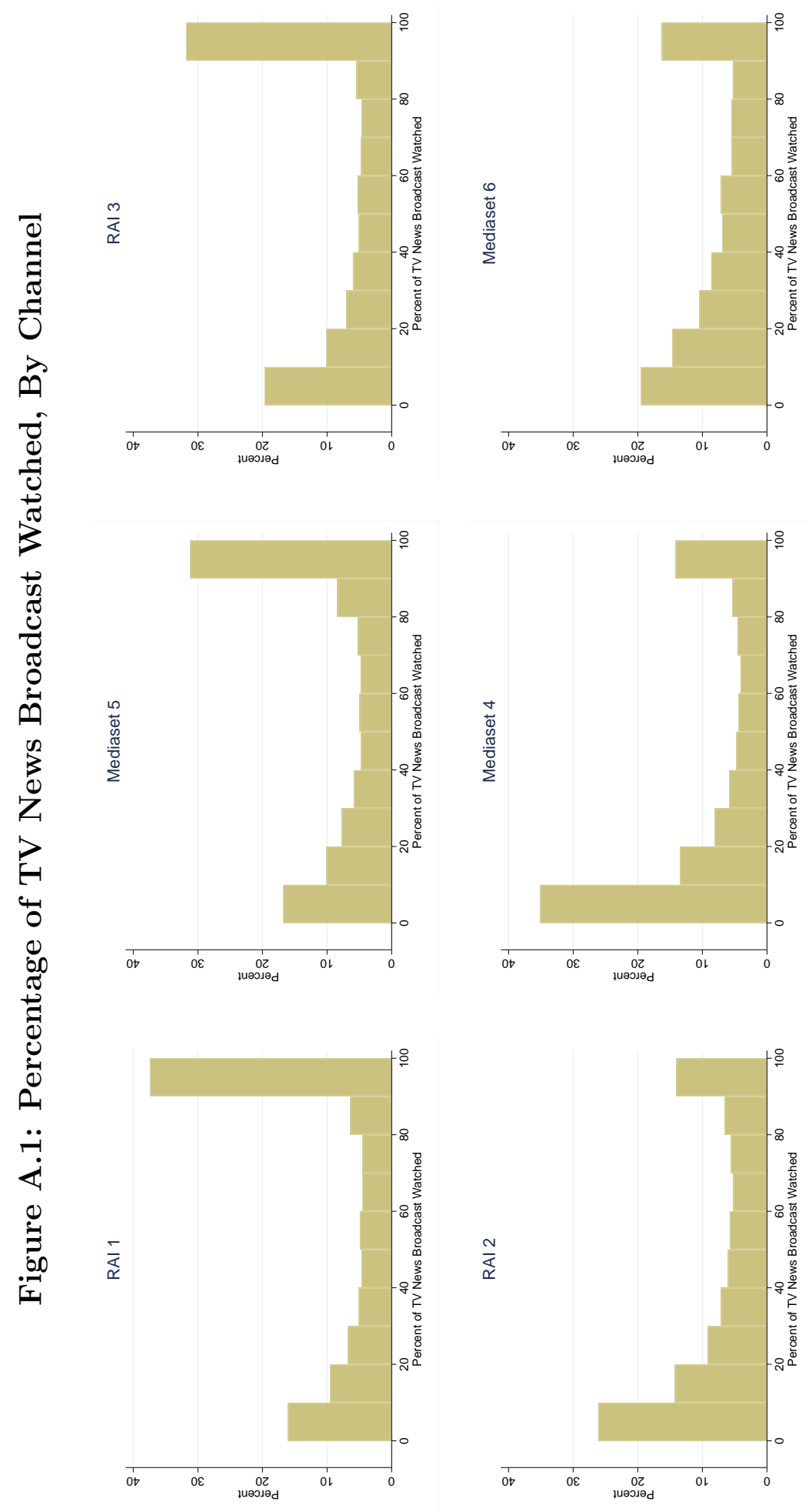




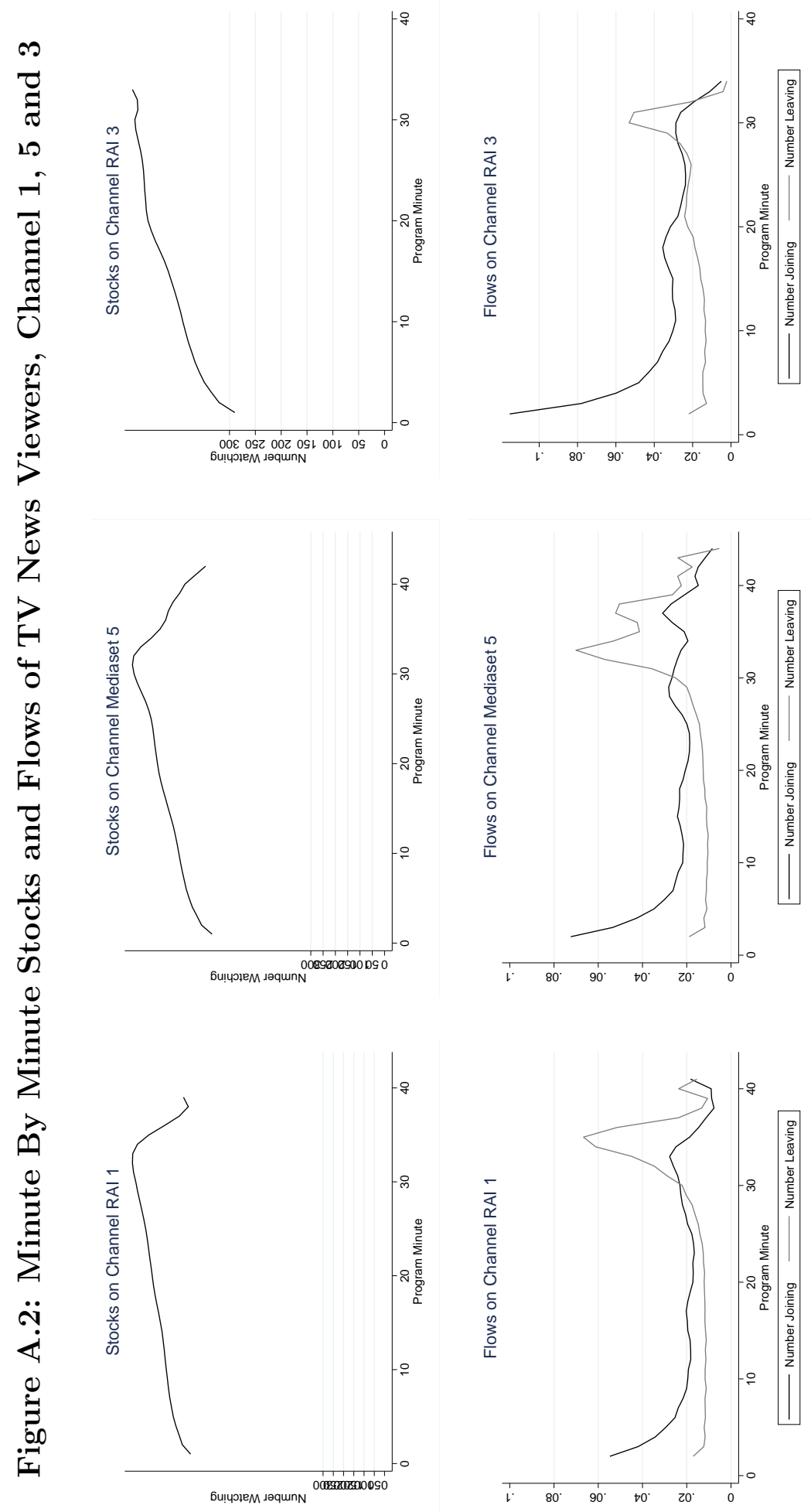




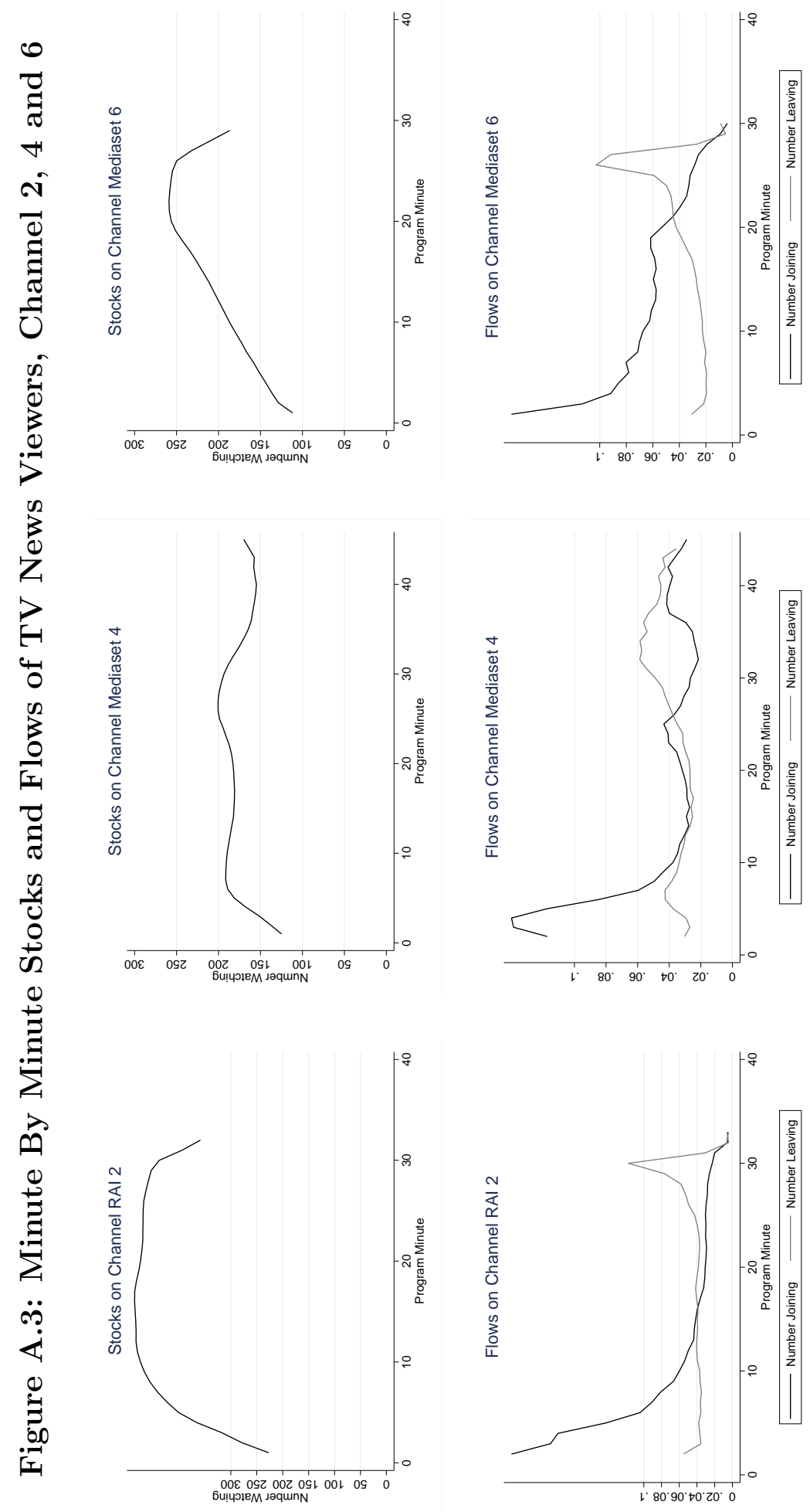



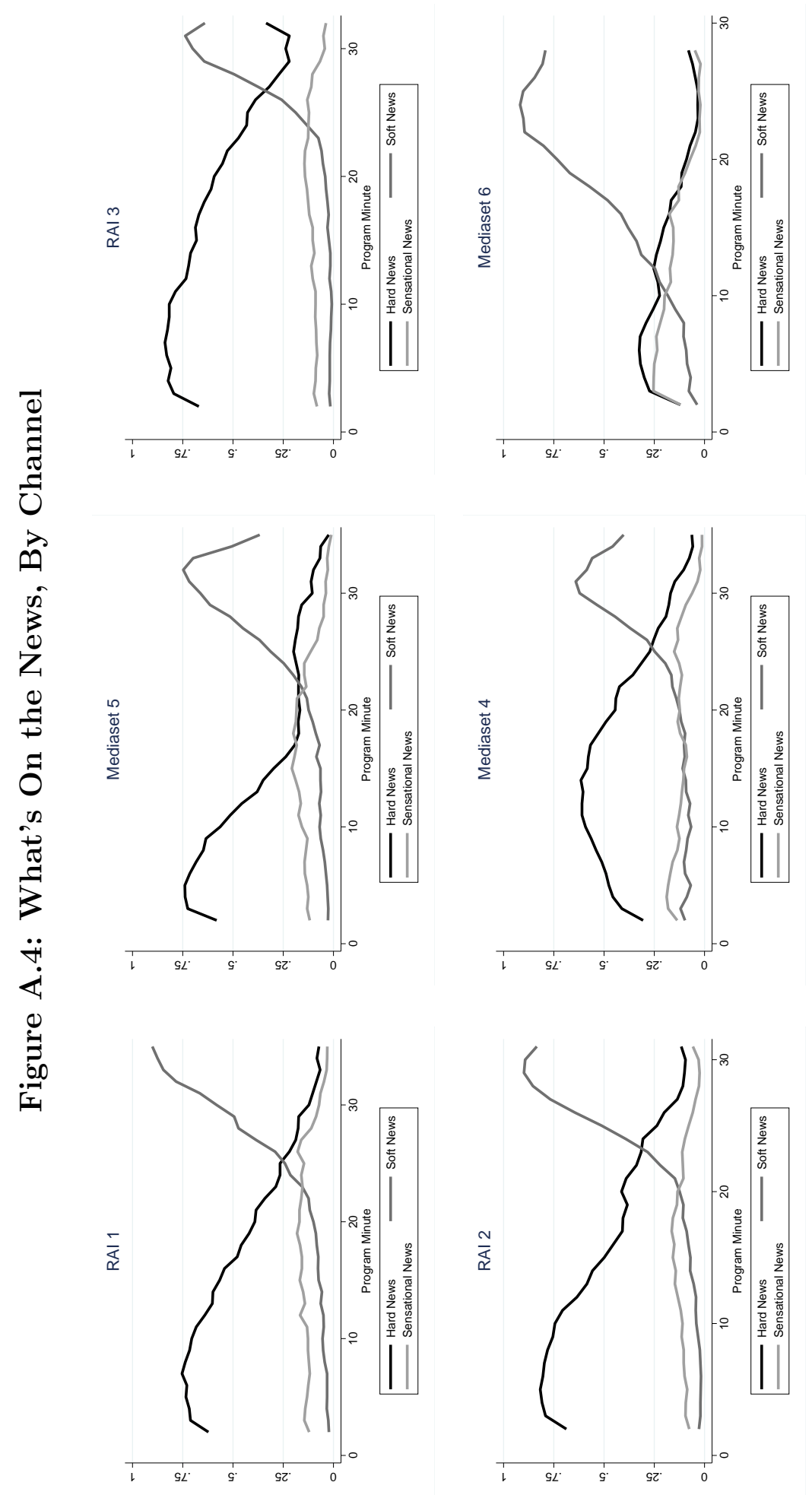
Table A.1: Viewer Switching Behavior, by Gender $(\mathrm{DV}=$ Percent of Time Viewer Switched Away From Channel)

\begin{tabular}{lccccccc}
\hline \hline & & & & Block & & \\
Variable & 1 & 2 & 3 & 4 & 5 & 6 & 7 \\
\hline Male & & & & & & & \\
Soft News & -0.102 & 0.139 & 0.076 & 0.146 & 0.258 & 0.394 & 1.221 \\
& $(0.047)$ & $(0.034)$ & $(0.029)$ & $(0.028)$ & $(0.022)$ & $(0.021)$ & $(0.042)$ \\
Hard News & -0.020 & 0.111 & 0.100 & 0.078 & -0.010 & -0.179 & 0.059 \\
& $(0.022)$ & $(0.019)$ & $(0.017)$ & $(0.017)$ & $(0.017)$ & $(0.021)$ & $(0.051)$ \\
Sensational News & -0.165 & -0.044 & -0.142 & -0.157 & -0.147 & -0.140 & -0.316 \\
& $(0.022)$ & $(0.019)$ & $(0.017)$ & $(0.017)$ & $(0.015)$ & $(0.021)$ & $(0.057)$ \\
Observations & $3,225,066$ & $4,542,184$ & $4,780,624$ & $5,021,775$ & $5,178,231$ & $4,950,408$ & $2,793,399$ \\
\hline Female & & & & & & & \\
Soft News & -0.110 & 0.072 & 0.045 & 0.131 & 0.189 & 0.303 & 1.038 \\
Hard News & $(0.041)$ & $(0.026)$ & $(0.024)$ & $(0.022)$ & $(0.018)$ & $(0.016)$ & $(0.032)$ \\
& 0.089 & 0.110 & 0.129 & 0.120 & 0.047 & -0.116 & -0.013 \\
Sensational News & $-0.019)$ & $(0.015)$ & $(0.014)$ & $(0.014)$ & $(0.014)$ & $(0.017)$ & $(0.037)$ \\
& $(0.021)$ & -0.071 & -0.138 & -0.148 & -0.111 & -0.106 & -0.233 \\
Observations & $4,476,888$ & $6,152,988$ & $6,450,373$ & $6,756,959$ & $6,944,724$ & $6,672,393$ & $3,972,231$ \\
\hline p-value 1 & 0.027 & 0.005 & 0.339 & 0.248 & 0.005 & 0.000 & 0.062 \\
p-value 2 & 0.993 & 0.058 & 0.280 & 0.142 & 0.001 & 0.000 & 0.000 \\
\hline
\end{tabular}

Fixed effects for channel and program minute included in all specifications. Standard errors, clustered by individual, are in parentheses. p-value 1 is for F-test of H0: Soft News - Hard News for Males = Soft News - Hard News for Females. p-value 2 is for F-test of H0: Soft News - Sensational News for Males = Soft News - Sensational News for Females. 
Table A.2: Viewer Switching Behavior, by Age $(\mathrm{DV}=$ Percent of Time Viewer Switched Away From Channel)

\begin{tabular}{|c|c|c|c|c|c|c|c|}
\hline \multirow[b]{2}{*}{ Variable } & \multicolumn{7}{|c|}{ Block } \\
\hline & 1 & 2 & 3 & 4 & 5 & 6 & 7 \\
\hline \multicolumn{8}{|l|}{ Age 18-39 } \\
\hline Soft News & $\begin{array}{l}-0.094 \\
(0.091)\end{array}$ & $\begin{array}{c}0.083 \\
(0.059)\end{array}$ & $\begin{array}{l}-0.040 \\
(0.048)\end{array}$ & $\begin{array}{c}0.009 \\
(0.044)\end{array}$ & $\begin{array}{c}0.088 \\
(0.033)\end{array}$ & $\begin{array}{c}0.265 \\
(0.034)\end{array}$ & $\begin{array}{c}1.047 \\
(0.063)\end{array}$ \\
\hline Hard News & $\begin{array}{c}0.102 \\
(0.043)\end{array}$ & $\begin{array}{c}0.125 \\
(0.032)\end{array}$ & $\begin{array}{c}0.173 \\
(0.031)\end{array}$ & $\begin{array}{c}0.109 \\
(0.030)\end{array}$ & $\begin{array}{c}0.082 \\
(0.030)\end{array}$ & $\begin{array}{l}-0.094 \\
(0.036)\end{array}$ & $\begin{array}{c}0.124 \\
(0.078)\end{array}$ \\
\hline Sensational News & $\begin{array}{l}-0.199 \\
(0.048)\end{array}$ & $\begin{array}{l}-0.051 \\
(0.033)\end{array}$ & $\begin{array}{l}-0.155 \\
(0.030)\end{array}$ & $\begin{array}{l}-0.169 \\
(0.028)\end{array}$ & $\begin{array}{l}-0.101 \\
(0.026)\end{array}$ & $\begin{array}{l}-0.015 \\
(0.036)\end{array}$ & $\begin{array}{l}-0.213 \\
(0.091)\end{array}$ \\
\hline Observations & $1,046,022$ & $1,476,536$ & $1,580,595$ & $1,694,369$ & $1,784,335$ & $1,690,769$ & 989,567 \\
\hline \multicolumn{8}{|l|}{ Age 40-64 } \\
\hline Soft News & $\begin{array}{l}-0.112 \\
(0.047)\end{array}$ & $\begin{array}{c}0.114 \\
(0.031)\end{array}$ & $\begin{array}{c}0.059 \\
(0.028)\end{array}$ & $\begin{array}{c}0.110 \\
(0.025)\end{array}$ & $\begin{array}{c}0.207 \\
(0.020)\end{array}$ & $\begin{array}{c}0.355 \\
(0.019)\end{array}$ & $\begin{array}{c}1.187 \\
(0.038)\end{array}$ \\
\hline Hard News & $\begin{array}{c}0.077 \\
(0.021)\end{array}$ & $\begin{array}{c}0.124 \\
(0.018)\end{array}$ & $\begin{array}{c}0.143 \\
(0.016)\end{array}$ & $\begin{array}{c}0.130 \\
(0.017)\end{array}$ & $\begin{array}{c}0.043 \\
(0.016)\end{array}$ & $\begin{array}{l}-0.133 \\
(0.020)\end{array}$ & $\begin{array}{c}0.031 \\
(0.046)\end{array}$ \\
\hline Sensational News & $\begin{array}{l}-0.192 \\
(0.022)\end{array}$ & $\begin{array}{l}-0.075 \\
(0.018)\end{array}$ & $\begin{array}{l}-0.151 \\
(0.016)\end{array}$ & $\begin{array}{l}-0.136 \\
(0.016)\end{array}$ & $\begin{array}{l}-0.115 \\
(0.014)\end{array}$ & $\begin{array}{l}-0.108 \\
(0.019)\end{array}$ & $\begin{array}{l}-0.330 \\
(0.053)\end{array}$ \\
\hline Observations & $3,397,875$ & $4,785,672$ & $5,071,882$ & $5,362,496$ & $5,565,976$ & $5,340,739$ & $3,036,064$ \\
\hline \multicolumn{8}{|l|}{ Age 65-99 } \\
\hline Soft News & $\begin{array}{l}-0.103 \\
(0.044)\end{array}$ & $\begin{array}{c}0.091 \\
(0.032)\end{array}$ & $\begin{array}{c}0.097 \\
(0.029)\end{array}$ & $\begin{array}{c}0.231 \\
(0.029)\end{array}$ & $\begin{array}{c}0.285 \\
(0.023)\end{array}$ & $\begin{array}{c}0.354 \\
(0.021)\end{array}$ & $\begin{array}{c}1.059 \\
(0.041)\end{array}$ \\
\hline Hard News & $\begin{array}{c}0.001 \\
(0.021)\end{array}$ & $\begin{array}{c}0.103 \\
(0.018)\end{array}$ & $\begin{array}{c}0.071 \\
(0.016)\end{array}$ & $\begin{array}{c}0.072 \\
(0.016)\end{array}$ & $\begin{array}{l}-0.019 \\
(0.017)\end{array}$ & $\begin{array}{l}-0.168 \\
(0.021)\end{array}$ & $\begin{array}{l}-0.037 \\
(0.046)\end{array}$ \\
\hline Sensational News & $\begin{array}{l}-0.164 \\
(0.023)\end{array}$ & $\begin{array}{l}-0.046 \\
(0.018)\end{array}$ & $\begin{array}{l}-0.123 \\
(0.016)\end{array}$ & $\begin{array}{l}-0.166 \\
(0.016)\end{array}$ & $\begin{array}{l}-0.150 \\
(0.015)\end{array}$ & $\begin{array}{l}-0.173 \\
(0.020)\end{array}$ & $\begin{array}{l}-0.218 \\
(0.055)\end{array}$ \\
\hline Observations & $3,258,057$ & $4,432,964$ & $4,578,520$ & $4,721,869$ & $4,772,644$ & $4,591,293$ & $2,739,999$ \\
\hline $\mathrm{p}$-value 1 & 0.956 & 0.695 & 0.000 & 0.000 & 0.000 & 0.000 & 0.960 \\
\hline p-value 2 & 0.781 & 0.110 & 0.000 & 0.000 & 0.000 & 0.000 & 0.023 \\
\hline
\end{tabular}

Fixed effects for channel and program minute included in all specifications. Standard errors, clustered by individual, are in parentheses. p-value 1 is for F-test of H0: Soft News - Hard News for Ages 18-39= Soft News - Hard News for Ages 65-99. p-value 2 is for F-test of H0: Soft News - Sensational News for Ages 18-39 = Soft News - Sensational News for Ages 65-99. 
Table A.3: Viewer Switching Behavior

DV $=$ Percent of Time Viewer Switched Away From Channel)

\begin{tabular}{|c|c|c|c|c|c|c|c|}
\hline \multirow[b]{2}{*}{ Variable } & \multicolumn{7}{|c|}{ Block } \\
\hline & 1 & 2 & 3 & 4 & 5 & 6 & 7 \\
\hline \multicolumn{8}{|l|}{ Channel 1} \\
\hline \multirow[t]{2}{*}{ Soft News } & -0.155 & 0.104 & 0.077 & 0.125 & 0.096 & 0.233 & 1.037 \\
\hline & $(0.043)$ & $(0.031)$ & $(0.027)$ & $(0.023)$ & $(0.018)$ & $(0.017)$ & $(0.033)$ \\
\hline \multirow[t]{2}{*}{ Hard News } & 0.030 & 0.106 & 0.088 & 0.089 & 0.081 & 0.035 & -0.309 \\
\hline & $(0.020)$ & $(0.017)$ & $(0.015)$ & $(0.014)$ & $(0.014)$ & $(0.018)$ & $(0.040)$ \\
\hline \multirow[t]{2}{*}{ Sensational News } & -0.187 & -0.060 & -0.119 & -0.085 & -0.067 & -0.112 & 0.123 \\
\hline & $(0.021)$ & $(0.017)$ & $(0.015)$ & $(0.014)$ & $(0.013)$ & $(0.017)$ & $(0.045)$ \\
\hline Observations & $2,777,962$ & $3,623,315$ & $3,717,719$ & $3,849,723$ & $3,964,406$ & $4,086,248$ & $3,658,524$ \\
\hline \multicolumn{8}{|l|}{ Channel 2} \\
\hline \multirow[t]{2}{*}{ Soft News } & 0.013 & -0.381 & 0.119 & 0.187 & 0.521 & 1.002 & \\
\hline & $(0.129)$ & $(0.083)$ & $(0.070)$ & $(0.059)$ & $(0.042)$ & $(0.061)$ & \\
\hline \multirow[t]{2}{*}{ Hard News } & 0.060 & 0.322 & 0.356 & 0.157 & -0.034 & -0.747 & \\
\hline & $(0.058)$ & $(0.044)$ & $(0.042)$ & $(0.038)$ & $(0.037)$ & $(0.067)$ & \\
\hline \multirow[t]{2}{*}{ Sensational News } & -0.311 & -0.147 & -0.268 & -0.358 & -0.461 & -0.544 & \\
\hline & $(0.058)$ & $(0.044)$ & $(0.042)$ & $(0.039)$ & $(0.039)$ & $(0.077)$ & \\
\hline Observations & 950,888 & $1,575,610$ & $1,682,421$ & $1,676,342$ & $1,637,252$ & $1,439,894$ & \\
\hline Channel 3 & & & & & & & \\
\hline \multirow[t]{2}{*}{ Soft News } & -0.040 & 0.216 & -0.208 & 0.319 & 0.686 & 0.557 & \\
\hline & $(0.094)$ & $(0.095)$ & $(0.071)$ & $(0.068)$ & $(0.051)$ & $(0.039)$ & \\
\hline \multirow[t]{2}{*}{ Hard News } & -0.007 & -0.043 & -0.002 & 0.088 & -0.010 & -0.383 & \\
\hline & $(0.037)$ & $(0.033)$ & $(0.029)$ & $(0.028)$ & $(0.028)$ & $(0.035)$ & \\
\hline \multirow[t]{2}{*}{ Sensational News } & -0.151 & 0.034 & -0.100 & -0.063 & -0.058 & -0.494 & \\
\hline & $(0.037)$ & $(0.033)$ & $(0.029)$ & $(0.028)$ & $(0.027)$ & $(0.036)$ & \\
\hline Observations & 985,299 & $1,370,252$ & $1,469,323$ & $1,600,061$ & $1,676,623$ & $1,686,375$ & \\
\hline \multicolumn{8}{|l|}{ Channel 4} \\
\hline \multirow[t]{2}{*}{ Soft News } & 0.132 & 0.731 & 0.120 & 0.010 & 0.104 & 0.101 & 0.637 \\
\hline & $(0.109)$ & $(0.118)$ & $(0.093)$ & $(0.078)$ & $(0.068)$ & $(0.069)$ & $(0.102)$ \\
\hline \multirow[t]{2}{*}{ Hard News } & 0.055 & 0.156 & -0.027 & 0.043 & 0.047 & -0.450 & 0.307 \\
\hline & $(0.069)$ & $(0.070)$ & $(0.058)$ & $(0.057)$ & $(0.055)$ & $(0.068)$ & $(0.124)$ \\
\hline \multirow[t]{2}{*}{ Sensational News } & 0.059 & 0.028 & -0.063 & -0.181 & -0.243 & -0.717 & -0.478 \\
\hline & $(0.070)$ & $(0.074)$ & $(0.061)$ & $(0.054)$ & $(0.054)$ & $(0.071)$ & $(0.175)$ \\
\hline Observations & 370,011 & 553,133 & 535,884 & 527,602 & 555,268 & 568,614 & 359,052 \\
\hline \multicolumn{8}{|l|}{ Channel 5} \\
\hline \multirow[t]{2}{*}{ Soft News } & -0.153 & -0.051 & 0.038 & 0.007 & 0.086 & 0.199 & 0.915 \\
\hline & $(0.052)$ & $(0.028)$ & $(0.027)$ & $(0.024)$ & $(0.018)$ & $(0.017)$ & $(0.039)$ \\
\hline Hard News & 0.015 & 0.063 & 0.072 & 0.108 & 0.031 & -0.046 & 0.252 \\
\hline & $(0.024)$ & $(0.016)$ & $(0.016)$ & $(0.017)$ & $(0.017)$ & $(0.019)$ & $(0.051)$ \\
\hline Sensational News & -0.217 & -0.051 & -0.096 & -0.108 & -0.079 & -0.165 & -0.873 \\
\hline & $(0.024)$ & $(0.016)$ & $(0.016)$ & $(0.015)$ & $(0.014)$ & $(0.020)$ & $(0.058)$ \\
\hline Observations & $2,223,830$ & $2,964,927$ & $3,102,730$ & $3,275,057$ & $3,385,186$ & $3,564,989$ & $2,416,404$ \\
\hline Channel 6 & & & & & & & \\
\hline Soft News & -0.107 & 0.260 & 0.024 & 0.056 & -0.106 & & \\
\hline & $(0.096)$ & $(0.063)$ & $(0.050)$ & $(0.054)$ & $(0.085)$ & & \\
\hline Hard News & 0.253 & 0.226 & 0.335 & 0.281 & 0.079 & & \\
\hline & $(0.063)$ & $(0.049)$ & $(0.050)$ & $(0.064)$ & $(0.117)$ & & \\
\hline Sensational News & -0.089 & -0.106 & -0.234 & -0.311 & -0.193 & & \\
\hline & $(0.058)$ & $(0.046)$ & $(0.044)$ & $(0.053)$ & $(0.097)$ & & \\
\hline Observations & 393,964 & 607,935 & 722,920 & 849,949 & 904,220 & & \\
\hline
\end{tabular}

Fixed effects for program minute included in all specifications. Standard errors, clustered by individual, are in parentheses. 